\title{
Structural Characterization of GASDALIE Fc Bound to the Activating Fc receptor $\mathrm{Fc} \gamma \mathrm{R}$ Illa
}

Alysia A. Ahmed ${ }^{1 \dagger}$, Sravya R. Keremane ${ }^{1}$, Jost Vielmetter ${ }^{1}$, Pamela J. Bjorkman ${ }^{1,2}$

${ }^{1}$ Division of Biology and Biological Engineering 114-96, California Institute of Technology, 1200 East California Boulevard, Pasadena, CA 91125, USA

†Present address: Departments of Structural Biology and Molecular and Cellular Physiology, Stanford University, Stanford, CA 94305, USA

${ }^{2}$ To whom correspondence should be addressed. E-mail: bjorkman@caltech.edu

Phone: (626) 395-8350 Fax: (626) 792-3683 


\section{Abstract}

The Fc region of Immunoglobulin $\mathrm{G}(\mathrm{lg} G)$ initiates inflammatory responses such as antibody-dependent cell-mediated cytotoxicity (ADCC) through binding to activating Fc

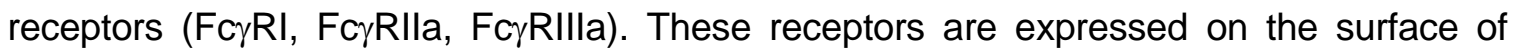
immune cells including macrophages, dendritic cells, and natural killer cells. An inhibitory receptor, Fc $\gamma \mathrm{R}$ llb, is expressed on macrophages and other myeloid leukocytes simultaneously with the activating receptor FcyRlla, thereby setting a threshold for cell activation. The affinity of $\lg$ Fc for binding activating Fc receptors depends on $\lg G$ subclass and the composition of $\mathrm{N}$-linked glycans attached to a conserved asparagine in the $\mathrm{Fc}_{\mathrm{C}} \mathrm{C}_{\mathrm{H}}$ domain. For example, $\mathrm{Fc}$ regions with afucosylated glycans bind more tightly to FcyRllla than fucosylated Fc, and afucosylated Fcs exhibit enhanced ADCC activity in vivo and in vitro. Enhanced pro-inflammatory responses have also been seen for Fc regions with amino acid substitutions. GASDALIE $\mathrm{FC}$ is an $\mathrm{Fc}$ mutant (G236A/S239D/A330L/I332E) that exhibits a higher affinity for FcyRllla and increased effector functions in vivo compared to wild-type Fc. To explore its altered functions, we compared the affinities of GASDALIE and wild-type Fc for activating and inhibitory FcyRs. We also determined the crystal structure of GASDALIE Fc alone and bound to FcyRllla. The overall structure of GASDALIE Fc alone was similar to wild-type Fc structures, however, increased electrostatic interactions in the GASDALIE Fc:Fc $\gamma$ RIlla interface compared with other Fc:Fc $\gamma R$ structures suggest a mechanism for the increased affinity of GASDALIE Fc for FcyRIIla.

\section{Keywords}

Affinity, Fc-FcR structure, Fc receptors, GASDALIE Fc, IgG Fc, SDALIE Fc 


\section{Abbreviations}

ADCC, antibody-dependent cell-mediated cytotoxicity; ADCP, antibody-dependent cellular phagocytosis; Fc, fragment crystallizable; Fc $\gamma \mathrm{R}$, Fc gamma receptor; GlcNAc, Nacetylglucosamine; $K_{D}$, equilibrium dissociation constant; IgG, immunoglobulin $G, I C$, immune complex; ITAM, immunoreceptor tyrosine-based activating motif; ITIM, immunoreceptor tyrosine-based inhibitory motif; SPR, surface plasmon resonance; wt, wild-type.

\section{Introduction}

Immunoglobulin $\mathrm{G}(\mathrm{lg} G)$ plays critical roles in antibody-mediated immune responses through specific engagement of both antigens and immune effector cells. The fragment crystallizable (Fc) region specifically engages Fc gamma receptors (Fc $\gamma R s)$, the initial step in effector functions such as antibody-dependent cell-mediated cytotoxicity (ADCC) and antibody-dependent cellular phagocytosis (ADCP) (Arnold et al., 2007). In humans, activating Fc $\gamma R$ FcyRIIla (CD16) is expressed on the surface of natural killer cells and monocytes while FcyRlla (CD32) is found on a wider range of innate immune cells including macrophages, dendritic cells, and neutrophils (DiLillo and Ravetch, 2015b; Richards et al., 2008). Both are low-affinity receptors, therefore activation of cells results from crosslinking of these surface receptors upon engagement of clustered Fc regions in antibody-antigen immune complexes (ICs) (Nimmerjahn and Ravetch, 2008). Activation is mediated by immunoreceptor tyrosine-based activating motifs (ITAMs) found on the receptor-associated $\gamma$-chain. Upon engagement of ICs with FcyRs, these motifs become phosphorylated leading to a cascade of events that activate the cell to destroy an invading pathogen or infected cell (Nimmerjahn and Ravetch, 2008). An inhibitory receptor, Fc $\gamma R$ Illb, is found on cells including B cells, macrophages, neutrophils, and mast cells 
(Hulett and Hogarth, 1994; Ravetch and Bolland, 2001; Ravetch and Kinet, 1991). Immunoreceptor tyrosine-based inhibitory motifs (ITIMs) in the cytoplasmic tail of Fc $\gamma$ RIIb mediate suppression of $\mathrm{Fc} \gamma \mathrm{R}$ activation by activating phosphatases that reverse the effects of kinases in the ITAM signaling pathway (Nimmerjahn and Ravetch, 2008). Coexpression of activating and inhibitory receptors sets a threshold for activation of specific effector cells.

IgG Fc regions are independently-folded, stable homodimers comprising two Nterminal hinges (each connected to an antigen-binding Fab arm) followed by two Ig constant domains, $\mathrm{C}_{\mathrm{H}} 2$ and $\mathrm{C}_{\mathrm{H}} 3$, on each chain of the homodimer. Fc $\gamma$ Rs bind asymmetrically to $\mathrm{Fc}$ homodimers with $1: 1$ receptor:Fc stoichiometry to a site involving the hinge region and $\mathrm{N}$-terminal portions of the $\mathrm{C}_{\mathrm{H}} 2$ domains (Ferrara et al., 2011). The Fc region includes a heterogeneous $N$-linked glycan attached to a conserved residue, Asn297, in each $\mathrm{Fc} \mathrm{C}_{\mathrm{H}} 2$ domain. The Asn297-linked glycan is a complex carbohydrate composed of a mannose (Man) and N-acetylglucosamine (GlcNAc) core that is usually fucosylated. The glycan can be additionally modified with a terminal galactose or sialic acid. Typically, wild-type (wt) lgG is agalactosylated (G0; 35\%), mono-galactosylated (G1; $35 \%$ ), or digalactosylated (G2; 16\%) and asialylated (S0; 85\%), although mono- and disialylated IgG represent $11 \%$ and $4 \%$, respectively, of IgG in human serum (Butler et al., 2003). Modification of the $N$-linked glycan of IgG Fc can alter its function. For example, terminally sialylating the glycan switches the Fc from a pro-inflammatory to antiinflammatory molecule (Anthony et al., 2011; Anthony et al., 2008a; Anthony and Ravetch, 2010; Anthony et al., 2008b; Kaneko et al., 2006; Nimmerjahn and Ravetch, 2008; Samuelsson et al., 2001; Sondermann et al., 2013), which may correlate with increased conformational flexibility compared with wtFc regions (Ahmed et al., 2014). Afucosylation of the normally core-fucosylated glycan leads to enhanced binding to the activating 
receptor FC $\gamma R$ IIlla, resulting in enhanced ADCC (Ferrara et al., 2011; Matsumiya et al., 2007; Mizushima et al., 2011; Okazaki et al., 2004) due to increased protein-protein and protein-carbohydrate interactions between the Fc and receptor (Ferrara et al., 2011; Matsumiya et al., 2007; Okazaki et al., 2004). Removing the $N$-linked glycan leads to a closed Fc conformation that exhibits no binding to any FcyR (Shields et al., 2001); however, aglycosylated Fc can bind the FcRn protection receptor (Shields et al., 2001), which recognizes the interface between the $\mathrm{C}_{\mathrm{H}} 2$ and $\mathrm{C}_{\mathrm{H}} 3$ domains of each $\mathrm{Fc}$ chain (Burmeister et al., 1994), a site distant from the Asn297-linked $N$-linked glycan.

Previous efforts were made to alter the $\lg G$ Fc region to either enhance or suppress binding to FcyRs (Bournazos et al., 2014a; Duncan et al., 1988; Ferrara et al., 2011; Lazar et al., 2006; Lin et al., 2015; Matsumiya et al., 2007; Nimmerjahn and Ravetch, 2008; Oganesyan et al., 2008a; Oganesyan et al., 2008b; Richards et al., 2008; Sazinsky et al., 2008; Shields et al., 2001). In a 2006 study, IgG Fc with mutations S239D//332E (SDIE) or S239D/A330L/I332E (SDALIE) showed enhanced ADCC and increased affinity for binding to FcyRllla $\mathrm{F}_{158}$ (30- and 60-fold for SDIE Fc and 60- and 170fold for SDALIE Fc) (Lazar et al., 2006). In a separate study, SDIE Fc showed a 30-fold

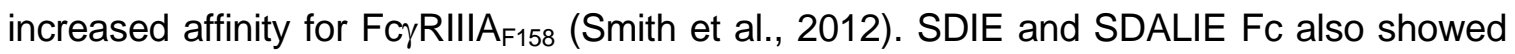
increased binding to the inhibitory receptor, Fc $\gamma R \mathrm{Rllb}$, by 70 -fold and 40 -fold, respectively (Lazar et al., 2006; Oganesyan et al., 2008a; Smith et al., 2012). A later study reported only a 14-fold increased affinity for SDIE binding to FcyRllb (Smith et al., 2012). The crystal structure of unbound SDALIE Fc revealed a more open conformation compared with wtFc structures, but no major changes in the $\mathrm{Fc} \gamma \mathrm{R}$ recognition interface (Oganesyan et al., 2008a). Related Fc mutants also showed increased activity and affinity for binding to

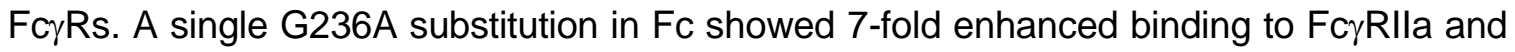
enhanced phagocytosis in vitro, while an Fc with mutations G236A/S239D//332E 
(GASDIE) exhibited a 70-fold phagocytosis enhancement (Richards et al., 2008). The G236A substitution alone did not cause enhanced binding to FcyRllb, whereas the GASDIE mutant showed 14-fold enhanced affinity for this inhibitory receptor (Richards et al., 2008). GASDALIE Fc, a variant of SDALIE Fc that combined the G236A substitution with the SDALIE substitutions (G236A/S239D/A330L/I332E), showed increased affinity for activating receptor FcyRllla $\mathrm{F}_{158}$ by 20-30-fold (Bournazos et al., 2014b; DiLillo and Ravetch, 2015a; Smith et al., 2012). Unlike SDALIE Fc, GASDALIE Fc did not exhibit a large increase in affinity for the inhibitory receptor FcyRllb (only a 2-3-fold increase for GASDALIE, as compared with a 40-fold increase for SDALIE), (Bournazos et al., 2014b; DiLillo and Ravetch, 2015a; Smith et al., 2012).

IgGs with the GASDALIE mutations have recently been shown to exhibit increased protection in animal models of cancer and infectious disease (Bournazos et al., 2014b; DiLillo and Ravetch, 2015a; Smith et al., 2012). Although affinities of GASDALIE and SDALIE Fcs have been measured for some of the FcyRs (Bournazos et al., 2014a; Bournazos et al., 2014b; DiLillo and Ravetch, 2015a; Oganesyan et al., 2008a; Richards et al., 2008; Sazinsky et al., 2008; Smith et al., 2012), they have not been directly compared in a single experiment. In addition, there are discrepancies in reported affinities of Fc mutants for activating and inhibitory FcyRs (Bournazos et al., 2014a; Bournazos et al., 2014b; DiLillo and Ravetch, 2015a; Richards et al., 2008; Sazinsky et al., 2008; Smith et al., 2012). Here we directly compared binding of GASDALIE and SDALIE Fc to Fc $\gamma R s$, finding that both Fcs exhibited large affinity increases for FçRllla compared to wtFc, that GASDALIE exhibited a moderate affinity increase for FcyRlla compared with wtFc, and that both Fcs showed only $\sim 5$-fold enhanced affinity for the inhibitory Fc $\gamma R$ Rllb receptor compared to wtFc. In order to determine the mechanism by which the GASDALIE substitutions enhanced binding to activating Fc $\gamma R$ s, we solved crystal structures of 
GASDALIE Fc alone and in complex with FcyRllla, comparing the bound and free GASDALIE Fc structures to the previously-solved unbound SDALIE FC structure (Oganesyan et al., 2008a; Smith et al., 2012) and other Fc structures. We find that the GASDALIE substitutions did not dramatically alter the overall Fc conformation; however, the GASDALIE Fc:FcyRllla structure revealed increased electrostatic interactions at the binding interface that may account for its increased affinity for Fc $\gamma R$ Rllla when compared to wtFc structures. Our GASDALIE Fc:FcrRIlla crystal structure, homology models of GASDALIE Fc bound to FcyRlla, and affinity measurements suggested that the G236A substitution that distinguishes GASDALIE Fc from SDALIE Fc is localized in the FcyRlla binding site, thereby enhancing binding of FcyRlla to GASDALIE compared with binding to wtFc or SDALIE Fc.

\section{Materials and Methods}

\section{Protein Expression and Purification}

The S239D/A330L/I332E (SDALIE) and G236A/S239D/A330L/I332E (GASDALIE)

mutations were introduced by site-directed mutagenesis in a pcDNA3.1 vector containing the IgG1 Fc gene (Agilent Technologies). A plasmid containing the GASDALIE mutations (G236A/S239D/A330L/I332E) introduced into Fc region of the gene encoding the heavy chain of an anti-HIV-1 antibody, 3BNC117, was the gift of Stylianos Bournazos and Jeffrey Ravetch (Rockefeller University) (Bournazos et al., 2014b; Scheid et al., 2011). IgG and Fc proteins were expressed in transiently-transfected HEK 293-6E cells and purified from harvested supernatants using protein A chromatography (GE Healthcare) followed by size exclusion chromatography in $25 \mathrm{mM}$ Tris-Cl pH 7.5, $100 \mathrm{mM} \mathrm{NaCl}$ on a Superdex 200 
10/300 gel-filtration column (GE Healthcare) as described (Diskin et al., 2010; Sprague et al., 2004). The Fc region from 3BNC117 lgG was isolated after papain digestion of 3BNC117 GASDALIE IgG as described (Ahmed et al., 2014) and used for crystallization of GASDALIE Fc alone; other experiments used GASDALIE Fc expressed as an Fc fragment.

Expression plasmids encoding the F158 variant of FcyRIlla and the H131 variant of

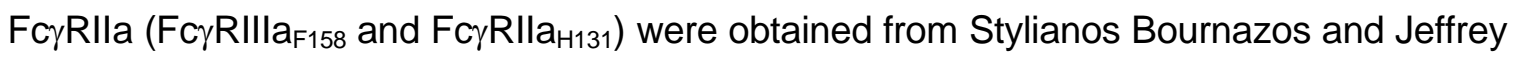
Ravetch (Rockefeller University) (Bournazos et al., 2014b). Site directed mutagenesis was used to remove three of five potential $N$-linked glycosylation sites on FcyRllla (Asn38, Asn74, Asn169) by changing asparagines to glutamines to make N38Q, N74Q, N169Q substitutions, as described for previous structural studies of FcyRIlla (Ferrara et al., 2011). Potential $N$-linked glycosylations sites at sites 45 and 162 were retained due to their effects on protein expression and binding affinity, respectively (Ferrara et al., 2011; Ferrara et al., 2006). C-terminally 6x-His tagged Fc $\gamma R$ ectodomains FcyRlla ${ }_{\text {H131 }}$ (residues 1-211) and $\mathrm{FC}_{\mathrm{C}} \mathrm{R} I \mathrm{ll} \mathrm{a}_{\mathrm{F} 158}$ (residues 1-218) were expressed in transiently-transfected HEK293 cells as described for Fc proteins and isolated from supernatants using a HisTrap HP affinity column (GE Healthcare) followed by size exclusion chromatography in $25 \mathrm{mM}$ Tris-Cl pH 7.5, $100 \mathrm{mM} \mathrm{NaCl}$ on a Superdex 200 16/ 60 gel-filtration column (GE Healthcare). To reduce carbohydrate heterogeneity that might impede crystallization, 2.5 $\mu \mathrm{M}$ kifunensine was added immediately before transfection of cells to inhibit processing of high-mannose $\mathrm{N}$-linked glycans to their complex forms (Edberg and Kimberly, 1997).

\section{Conventional SPR experiments}

Biacore assays were performed on a Biacore T200 instrument. Proteins were immobilized on a CM5 sensor chip using primary amine coupling chemistry (amine- 
coupling wizard routine in the Biacore T200 software). Briefly, $1 \mu \mathrm{M} \mathrm{Fc \gamma RIIIa}{ }_{\mathrm{F} 158}$, Fc $\gamma R R_{1 l a} a_{131}$, or Fc $\gamma R$ Illb in 10 mM sodium acetate buffer at pH 5.0 or pH 4.5 were coupled at a flow rate of $1 \mu \mathrm{L} /$ minute for 420 seconds followed by ethanolamine coupling to block excess reactive carboxyl groups on the sensor chip surface. The coupling density was

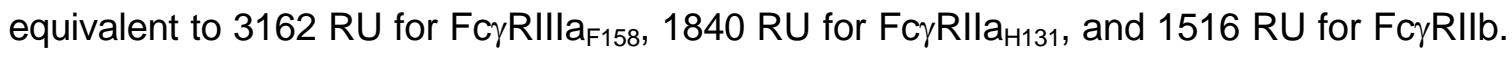
Flow channel 1 served as the blank reference channel for bulk refractive index subtraction. Serial dilutions starting at a concentration of $10,000 \mathrm{nM}$ of wtFc, SDALIE Fc, or GASDALIE Fc in HBSEP ${ }^{+}$buffer (10 mM HEPES, $150 \mathrm{mM} \mathrm{NaCl}, 3 \mathrm{mM}$ EDTA, and 0.05\% (v/v) surfactant P20, $\mathrm{pH} 7.4$ ) were injected at a flow rate of $30 \mu \mathrm{L} /$ minute at $25^{\circ} \mathrm{C}$ followed by a 200 second dissociation phase during which only $\mathrm{HBSEP}^{+}$buffer was injected. 10 $\mathrm{mM}$ glycine $\mathrm{pH} 3$ at $30 \mu \mathrm{L} /$ minute for 30 seconds was used for regeneration.

Sensorgrams were globally fitted to a 1:1 binding model using nonlinear regression in the Biaevaluation software. The fits were evaluated by plotting residuals between modeled and experimental curves. For comparisons with previously reported affinity measurements (Bournazos et al., 2014a; Bournazos et al., 2014b; Bruhns et al., 2009; DiLillo and Ravetch, 2015a; Janeway et al., 2005; Lazar et al., 2006; Smith et al., 2012), $K_{\mathrm{D}}$ values derived from these experiments are reported in Table 1 as conventional measurements and are calculated from the ratio of the kinetic constants as $K_{\mathrm{D}}=k_{\mathrm{d}} / k_{\mathrm{a}}$.

\section{Competition SPR experiments}

Competition SPR measurements were performed using methods similar to previously-reported competition Biacore studies (Nieba et al., 1996). Flow cell 1

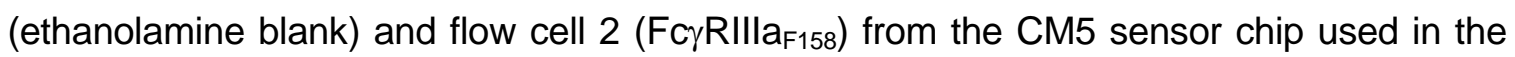

conventional SPR experiments were used for competition Biacore experiments. All measurements were carried out at $25{ }^{\circ} \mathrm{C}$ and a flow rate of $10 \mu \mathrm{L} /$ minute and an injection 
time period of 120 seconds using HBSEP ${ }^{+}$buffer. The chip was regenerated by injecting $10 \mathrm{mM}$ glycine $\mathrm{pH} 3$ at $30 \mu \mathrm{L}$ minute for 30 seconds. Each experimental cycle evaluating the binding of an Fc protein to a receptor consisted of $(I)$ Establishing a calibration curve to correlate the SPR response for each Fc protein binding to immobilized $\mathrm{Fc}_{\gamma} \mathrm{RIII} \mathrm{F}_{\mathrm{F} 158}$ as a function of concentration. For the calibration measurements, 2-fold dilution series of the Fc proteins including a no-protein standard (HBSEP ${ }^{+}$buffer only) were used starting at the following concentrations: $803 \mathrm{nM}$ (wtFc), $8 \mathrm{nM}$ (SDALIE Fc), $5 \mathrm{nM}$ (GASDALIE Fc). (ii) A

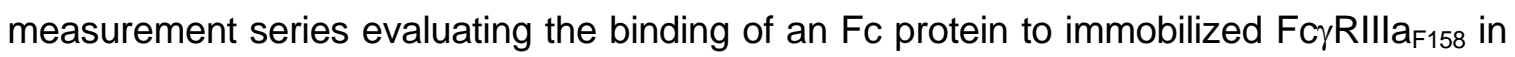
the presence of varying concentrations of competing $F c \gamma R$ in solution. For these measurements, a given Fc protein at a fixed concentration was first incubated for three hours with a 2-fold dilution series of a competitor receptor in solution. For wtFc injections, the concentration of wtFc was $401.5 \mathrm{nM}$ and the competitor dilution series starting

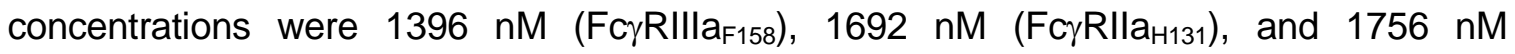
(FcyRllb). For SDALIE Fc injections, the concentration of SDALIE Fc was $4 \mathrm{nM}$ and the competitor dilution series starting concentrations were $87 \mathrm{nM}\left(\mathrm{F}_{\mathrm{C} \gamma \mathrm{R}} \mathrm{Illa} \mathrm{F}_{\mathrm{F} 158}\right), 1692 \mathrm{nM}$ (FcyRlla $\left.{ }_{H 131}\right)$, and $3512 \mathrm{nM}(\mathrm{Fc} \gamma \mathrm{R}$ Illb). For GASDALIE Fc injections, the concentration of GASDALIE Fc was $2.5 \mathrm{nM}$ and the competitor dilution series starting concentrations were

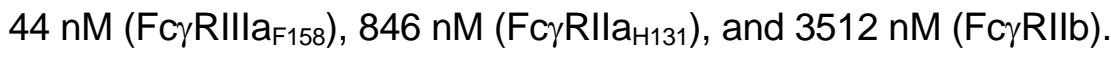

Data were analyzed using the Biacore T200 Evaluation software version 3.0. For the calibration curve, a 4-parameter fitting function was used. For calculation of the $K_{\mathrm{D}}$, the software uses a non-linear regression fit to the following function:

$B_{\text {free }}=\frac{\left(B_{t o t}-A_{t o t}-K_{D}\right)}{2} \pm \sqrt{\frac{\left(A_{t o t}+B_{t o t}+K_{D}\right)^{2}}{4}-A_{\text {tot }} \times B_{\text {tot }}}$

where variable $A_{\text {tot }}$ refers to the total concentration of the receptor in the Fc:FcyR mixture, $\mathrm{B}_{\text {free }}$ refers to the concentration of the unbound $\mathrm{Fc}$, and $\mathrm{B}_{\text {tot }}$ refers to the total concentration of $\mathrm{Fc}$ in the mixture. 
All curves were generated using the bulk refractive index subtracted response after an optimal injection time of 35 seconds (wtFc) or 144 seconds (SDALIE and GASDALIE Fc).

\section{Crystallization}

Crystals of GASDALIE Fc (space group P $2{ }_{1} 2{ }_{1} 2_{1} ; a=49.32 \AA, b=79.13 \AA, c=$ 137.62 Å; one Fc dimer per asymmetric unit) were grown in sitting drop vapor diffusion by mixing equal volumes of GASDALIE FC $(7.36 \mathrm{mg} / \mathrm{ml})$ with a solution containing $0.2 \mathrm{M}$ ammonium formate and $20 \%$ (w/v) PEG 3350 at $20^{\circ} \mathrm{C}$. Crystals were cryopreserved in well solution supplemented with $30 \%$ glycerol. Crystals of the GASDALIE Fc:Fc $\gamma$ RIIIa ${ }_{F 158}$ complex (space group $\mathrm{P} 2{ }_{1}{ }_{2}{ }_{1}{ }_{1} ; a=74.38 \AA ⿻, b=94.50 \AA, c=108.67 \AA$; one complex per asymmetric unit) were grown in sitting drop vapor diffusion by mixing equal volumes of protein $(10 \mathrm{mg} / \mathrm{ml})$ with a solution containing $0.04 \mathrm{M}$ potassium dihydrogen phosphate and $16 \%(w / v)$ PEG 8000 at $20^{\circ} \mathrm{C}$. The complex crystals were cryopreserved in well solution.

\section{Data Processing and Structure Determination}

Data were collected to $2.4 \AA$ resolution (GASDALIE Fc alone) and $3.1 \AA$ r resolution (Fc:Fc $\gamma R$ RIlla ${ }_{F 158}$ complex) at beamline 8.2.1 of the Advanced Light Source (ALS) at Lawrence Berkeley National Laboratory. Diffraction data were processed, indexed, integrated and scaled using iMosflm (Leslie and Powell, 2007) POINTLESS and SCALA, respectively (Evans, 2006; Evans, 2011). To determine the high-resolution cutoff for datasets, we used $I / \sigma \mathrm{I}$ ratios and completeness of the highest resolution shell in addition to the criterion that the $\mathrm{CC}_{1 / 2}$ statistic (correlation coefficient between two random halves of a data set) should be greater than 10\% (Karplus and Diederichs, 2012). We used Phenix (Adams et al., 2010) to compute $\mathrm{CC}_{1 / 2}$ values. Structures were solved by molecular 
replacement using PHASER (McCoy et al., 2007) and published Fc and Fc:FcrRIlla structures as search models (PDB codes 3DO3 and 3SGK). Modeling was done using COOT (Emsley et al., 2010). Crystallographic refinement was done using the Phenix crystallography package (Adams et al., 2010) by refining individual B factors for GASDALIE Fc and group B factors for the lower-resolution GASDALIE Fc:FcyRIIla $\mathrm{F}_{158}$ structure. We used PyMol (Schrödinger, 2011) for superposition calculations and molecular representations. Protein interfaces, surfaces and assemblies' service PISA at the European Bioinformatics Institute (Krissinel and Henrick, 2007) was used to determine hydrogen bonding and electrostatic interactions at the GASDALIE FC:FcyRIIIa $\mathrm{F}_{\mathrm{F} 58}$ interface.

The GASDALIE Fc model $\left(R_{\text {free }}=25.6 \% ; R_{\text {work }}=23.5 \%\right)$ included 416 protein residues in the GASDALIE Fc dimer (Leu235 - Ser444 on chain A and Gly237 - Ser444 on chain B), 18 glycan residues (GlcNAc1-Gal6, Fuc12 on chain A and GlcNAc1-GlcNAc8, Fuc12 on Chain B), and 105 water molecules.

The GASDALIE Fc: Fc $\gamma$ RIIla $a_{\text {F158 }}$ complex $\left(R_{\text {tree }}=29.6 \% ; R_{\text {work }}=27.1 \%\right)$ included 417 protein residues in the GASDALIE Fc dimer (Ala236-Ser444 on chain A and Ala236Leu443 on chain B), 17 Fc glycan residues (GlcNAc1-Gal6, Fuc12 on chain A and GlcNAc1-Gal6, Fuc12 on Chain B), 169 protein residues in the FcyRllla ${ }_{\mathrm{F} 158}$ ectodomain, and FcyRllla ${ }_{F 158}$ glycans GlcNAc1 attached to Asn162 and GlcNAc1 attached to Asn45. Side chains were disordered for residues Lys246, Lys248, Glu258, Glu269, Asp270, Glu272, Glu294, Tyr300, Lys326, and Arg355 on chain A, Lys246, Gln419 and Ser442 on chain B in the GASDALIE Fc dimer. No electron density was observed for side chains Phe11, Leu48, Ile49, Glu68, Gln72, Lys101, Glu103, Thr116, Lys128, Lys 143, Arg155, Gln174 and residues Tyr33-Ser39 and Ser75-Leu78 in the FcyRllla $\mathrm{F}_{158}$ ectodomain. 
Homology Modeling

We used Pymol (Schrödinger, 2011) to superimpose the D2 domains of FcyRlla (3RY4) or Fc $\gamma R$ RIlb (2FCB) to the D2 domain of FcyRIIla in the GASDALIE Fc:Fc $\gamma R$ IIIla ${ }_{F 158}$ complex and the wtFc:FcyRIllav158 complex (3SGJ) in order to generate homology models of GASDALIE Fc:Fc $\gamma R$ Rlla, GASDALIE Fc:Fc $\gamma R$ Rllb, wtFc:Fc $\gamma R$ Illa, and wtFc:Fc $\gamma R I l b$. The D2 domain of $F c \gamma R I I l a$ in the wtFc:FcyRIIlav158 structure was superimposed onto the D2 domain in the GASDALIE Fc:FcyRIIla ${ }_{F 158}$ complex to generate a GASDALIE Fc:Fc $\gamma R$ RIIlav158 homology model. PISA (Protein interfaces, surfaces and assemblies) service at the European Bioinformatics Institute (Krissinel and Henrick, 2007) was used to evaluate hydrogen bonding and electrostatic interactions at the GASDALIE Fc:Fc $\gamma R R_{I I l a}{ }_{v 158}$, GASDALIE Fc:Fc $\gamma R$ Rlla and wtFc:Fc $\gamma R I l a$ interfaces.

Results

Comparison of Affinities of Fc Variants for Activating and Inhibitory Fc $\gamma$ Rs

Activating Fc $\gamma$ Rs exist in variant forms in the human population depending on the amino acid identity at positions 158 (Phe158 or Val158 for FcyRIIla) or 131 (His131 or Arg131 for Fc $\gamma$ Rlla) (Ackerman and Nimmerjahn, 2014). The polymorphism at residue 158 of Fc $\gamma$ RIIla was reported to affect binding to Fcs: e.g., Fc $\gamma R \mathrm{RIII}_{\mathrm{F} 158}$ exhibited an $\sim 5$-fold lower affinity for wtFc compared to Fc $\gamma R$ RIlla ${ }_{v 158}$ (Bournazos et al., 2014b); however, there was no interaction between residue 158 of Fc $\gamma \mathrm{RIIla}$ and wtFc in the wtFc:Fc $\gamma \mathrm{RIIla}{ }_{\mathrm{v} 158} \mathrm{complex}$ structure (PDB 3SGJ). The histidine to arginine polymorphism at residue 131 of Fc $\gamma$ Rlla did not affect binding to wtFc of human IgG1 (Bournazos et al., 2014b), although Arg131 of $F c \gamma R I l a_{R 131}$ interacts with $F c$ in a wtFc:Fc $\gamma R$ Rlla $a_{R 131}$ complex structure (PDB 3RY6). For 
our studies, we expressed the Phe158 and His131 forms of Fc $\gamma \mathrm{RIIla}$ and Fc $\gamma \mathrm{RIla}$ $\left(\mathrm{Fc} \gamma \mathrm{RIIIa} \mathrm{F}_{158}\right.$ and $\left.\mathrm{Fc} \gamma \mathrm{RIla} \mathrm{H}_{\mathrm{H} 131}\right)$ for comparisons with previous in vitro and in vivo studies (Bournazos et al., 2014a; Bournazos et al., 2014b; DiLillo and Ravetch, 2015a; Oganesyan et al., 2008a; Richards et al., 2008; Sazinsky et al., 2008; Smith et al., 2012). Fc $\gamma R$ ectodomains, wtFc, and Fc variants were purified from supernatants of transiently-transfected mammalian cells as previously described (Diskin et al., 2010; Sprague et al., 2004). To attempt to resolve inconsistencies in the reported affinities of Fc mutants to FcyRs (Bournazos et al., 2014a; Bournazos et al., 2014b; Richards et al., 2008; Sazinsky et al., 2008; Smith et al., 2012) (Table 1), we first directly compared the affinities of wtFc, SDALIE Fc and GASDALIE Fc for binding to immobilized Fc $\gamma R_{\text {Illa }}{ }_{\mathrm{H} 131}, \mathrm{Fc} \gamma \mathrm{RIlb}$, or $\mathrm{Fc}_{\gamma} \mathrm{RIII}_{\mathrm{F} 158}$ using a surface plasmon resonance (SPR)-based binding assay in which equilibrium dissociation constants $\left(K_{D}\right.$ values) were calculated by determining the ratio of kinetic constants based on global fits of the association and dissociation phases of sensorgrams. However, we found that the binding data could not be accurately modeled by a 1:1 binding interaction (Fig. 1a). When we calculated $K_{\mathrm{D}}$ values using the poorly-fit models, we obtained results similar to some of the previous reports that obtained affinities using a 1:1 binding interaction to model $F c: F c \gamma R$ sensorgrams involving Fcs injected over immobilized FcyRs (Bournazos et al., 2014a; Bournazos et al., 2014b; Bruhns et al., 2009; DiLillo and Ravetch, 2015a; Janeway et al., 2005; Smith et al., 2012) (Table 1). However, higher affinities were reported for methods that did not involve measurements of affinities for immobilized FcyRs: for example, competition Biacore measurements (Lazar et al., 2006) (Table 1) or conventional SPR experiments in which the affinity of an injected Fc $\gamma R$ for immobilized Fc was derived (Oganesyan et al., 2008a; Richards et al., 2008). These results suggested the possibility of artifacts in experiments that derive affinities for direct interactions with immobilized Fc $\gamma$ Rs. 
To obtain consistent and more accurate comparisons of affinities, we used a measurement method similar to competition Biacore (Nieba et al., 1996) in which affinities

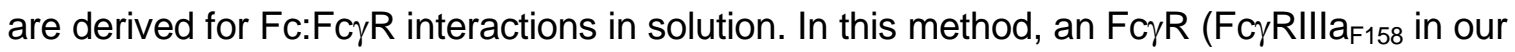
experiments) is immobilized on a sensor chip, and a constant concentration of Fc

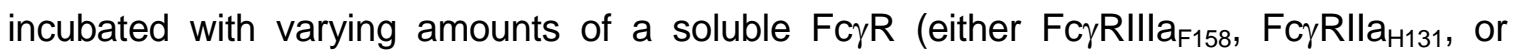

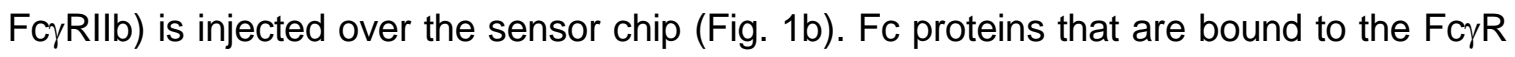
in solution are unable to bind the immobilized receptor. By measuring the amount of Fc that binds to immobilized receptor, we can calculate the concentration of Fc bound to the soluble FcyR. As the concentration of soluble receptor is decreased, fewer FcyR interactions with Fc occur in solution, and more of the unbound Fc is available to bind to the immobilized receptor. This allows for correlation of the SPR signal generated from unbound $\mathrm{Fc}$ in solution with a signal derived from an independent calibration experiment recording SPR signals from a series of known Fc concentrations. The concentration values derived this way are used together with known concentrations of total $\mathrm{Fc}$ and

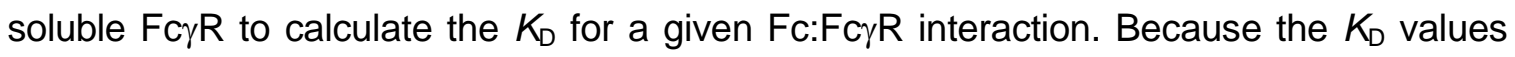
obtained using this method were higher than those derived in our own (Table 1) and in others' conventional SPR experiments (Bournazos et al., 2014a; Bournazos et al., 2014b; Bruhns et al., 2009; DiLillo and Ravetch, 2015a; Smith et al., 2012), we present the results as the fold improvement in the affinity of the SDALIE or GASDALIE Fc for a given Fc $\gamma R$ in Table 1 (i.e., $K_{\mathrm{D}}$ of $\mathrm{FC}$ mutant $/ K_{\mathrm{D}}$ of $\mathrm{wtFc}$ ). Given the poor fits of models to the conventional SPR measurements (Fig. 1a) compared with the excellent fits for the competition-based experiments (Fig. 1b), we based our comparisons of wtFc:Fc $\gamma R$ and mutant Fc:FcyR affinities on the competition-based experiments.

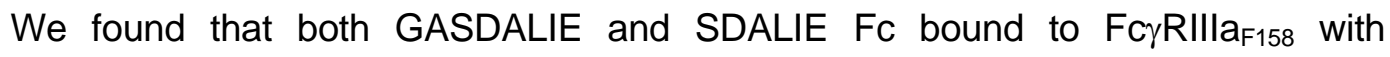
approximately the same increased affinity compared with wtFc (431-fold and 318-fold 
increases for GASDALIE and SDALIE, respectively) (Table 1). GASDALIE Fc bound to Fc $\gamma$ Rlla $_{\text {H131 }}$ 7-fold more tightly than did SDALIE Fc, with GASDALIE Fc showing 17-fold increased affinity for $F c \gamma R l l a_{H 131}$ compared to wtFc, but SDALIE Fc and wtFc showing approximately the same affinity for FcyRlla ${ }_{H 131}$ (within $\sim 2$-fold). Both GASDALIE Fc and SDALIE Fc had a similar increase in binding to the inhibitory receptor FcyRllb when compared to wtFc (5-6-fold). Although GASDALIE Fc and SDALIE Fc showed similar binding to $F c \gamma R I I I a_{F 158}$ and $F c \gamma R l l b$, the additional G236A mutation (GA in GASDALIE) further enhanced the affinity of GASDALIE Fc for Fc $\gamma \mathrm{Rlla}_{\mathrm{H} 131}$ when compared to SDALIE Fc (Table 1).

\section{Crystal Structure of GASDALIE FC Bound to FC $\gamma$ RIIla}

To facilitate crystallization of the GASDALIE Fc:Fc $\gamma R \mathrm{RIII}_{\mathrm{F} 158}$ complex, three of five potential $\mathrm{N}$-linked glycosylation sites on $\mathrm{F}_{\mathrm{C}} \mathrm{R} \mathrm{IIII}_{\mathrm{F} 158}$ were removed by site directed mutagenesis (N38Q, N74Q, N169Q). N-linked glycans at asparagines 45 and 162 were retained due to their effects on protein expression and Fc binding affinity, respectively (Ferrara et al., 2011; Ferrara et al., 2006). The complex structure was solved by molecular replacement using an afucosylated Fc:FcyRllla complex structure (PDB 3SGK) as a search model and refined to $3.1 \AA\left(R_{\text {cryst }}=0.27 ; R_{\text {free }}=0.29\right.$ ) (Supplementary Table 1$)$. $N$-linked glycans were built into electron density up to a terminal galactose on the 6-arm and up to a terminal GlcNAc on the 3-arm of Fc chains A and B (Supplementary Fig. 1a). On FcyRIIIa ${ }_{F 158}$, ordered electron density was observed for a GlcNAc attached to Asn45 and for a GlcNAc attached to N162 (Supplementary Fig. 1b). The sites of the GASDALIE substitutions (positions $236,239,330$, and 332 ) were visible in ordered electron density on Fc chains $A$ and B (Supplementary Fig. 1c). 
Similar to previous structures of Fc:Fc $\gamma R$ complexes (Ferrara et al., 2011; Matsumiya et al., 2007; Mizushima et al., 2011; Radaev et al., 2001), the GASDALIE Fc:FcyRllla $\mathrm{F}_{158}$ structure revealed an asymmetric 1:1 interaction in which the region connecting FcyRllla ${ }_{\mathrm{F} 158}$ domains 1 and 2 (D1 and D2) together with D2 loops BC, C'E and $F G$ interacted with the lower hinge region of $F c$ chains $A$ and $B$ and the $C_{H} 2$ domain $B C$, C'E and FG loops (Fig. 2a). Because the asymmetric binding of FcyRs to two-fold symmetric Fc regions results in different effects of the Fc substitutions on the two chains of the Fc homodimer, we will describe comparisons of the GASDALIE Fc:Fc $\gamma R \mathrm{RIII}_{\mathrm{F} 158}$ and

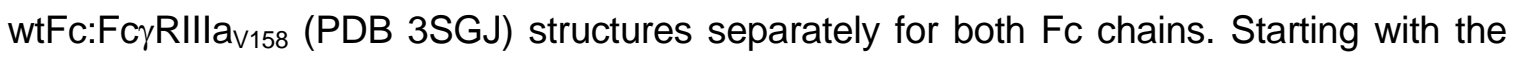
interactions of $\mathrm{Fc}$ chain $\mathrm{A}$ with $\mathrm{Fc} \gamma \mathrm{R} / \mathrm{Ila}_{\mathrm{F} 158}$, we found electrostatic interactions resulting from one of the GASDALIE substitutions, S239D, in which a positively-charged residue, Lys120, in the BC loop of FcyRIlla $\mathrm{F}_{158}$ D2 was positioned in a pocket between Fc chain A residues Asp239 (SD in GASDALIE) and Asp265 (Fig. 2b). By comparison, in the

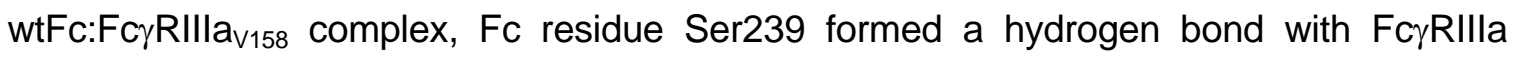
Lys120. The introduced residues Leu330 and Glu332, the AL and IE substitutions of GASDALIE, did not play a role in the interface of $\mathrm{Fc}_{\mathrm{C}} \mathrm{RIIl}_{\mathrm{F} 158}$ with chain A of GASDALIE Fc. Ala236 (the GA substitution in GASDALIE Fc) also was not at the binding interface; however, Gly236 in the wtFc:FcyRIllav158 complex formed a hydrogen bond with His135 of $\mathrm{F}_{\mathrm{C} \gamma \mathrm{R} I l \mathrm{la}} \mathrm{F}_{158}$ (Fig. 2b). The salt bridge formed by Asp239 on Fc chain A (SD substitution in GASDALIE FC and SDALIE Fc) and Lys120 of FcyRllla, which is not seen in wtFc:Fc $\gamma R$ Illa $a_{v 158}$ complex structures (Ferrara et al., 2011; Mimoto et al., 2013; Mizushima et al., 2011; Radaev et al., 2001; Sondermann et al., 2000), may contribute to the increased affinity of GASDALIE Fc for FcyRIIla, whereas the additional mutations G236A, A330L, and I332E do not participate in the interaction between GASDALIE FC chain A and $\mathrm{Fc}_{\gamma} \mathrm{RIIIa}_{\mathrm{F}_{158}}$. 
On chain B of GASDALIE Fc, we found new interactions with the introduction of the GASDALIE substitutions that may also contribute to the enhanced affinity for FC $\gamma$ RIIIa $_{\mathrm{F} 158}$ of GASDALIE compared to wtFc (Bournazos et al., 2014b; Smith et al., 2012) (Table 1). Lys161 in the FG loop of FcyRllla ${ }_{F 158}$ formed an electrostatic interaction with Fc chain B residue Glu332, the IE substitution in GASDALIE Fc, an interaction not seen in wtFc:Fc $\gamma$ RIIIIav158 complex structures since lle332 of wtFc did not interact with Fc $\gamma \mathrm{RIII} \mathrm{F}_{\mathrm{F} 158}$ Lys161 (Fig. 2c). Ala236, the GA substitution in GASDALIE Fc, makes a hydrophobic contact with Fc $\gamma$ RIIla residue Phe158; however, Fc residue Gly236 in the wtFc:Fc $\gamma R$ RIllav158 complex formed a hydrogen bond with Lys 161 of the receptor and did not contact receptor residue 158. Asp239 and Leu330 (the SD and AL substitutions in GASDALIE) on chain B were not at the binding interface with the receptor. The salt bridge formed by Glu332 on Fc chain B (IE substitution in GASDALIE Fc and SDALIE FC) and Lys161 of Fc $\gamma$ RIIIa $_{\mathrm{F} 158}$, and the hydrophobic interaction between Fc residue Ala236 and Fc $\gamma$ RIIla residue Phe158, which is not seen in wtFc:Fc $\gamma$ RIIlla ${ }_{\mathrm{v} 158}$ complex structures (Fig. 2c), may have contributed to the increased affinity of GASDALIE Fc to Fc $\gamma$ RIIla, whereas the additional mutations on chain B (S239D and A330L) did not participate in the interface.

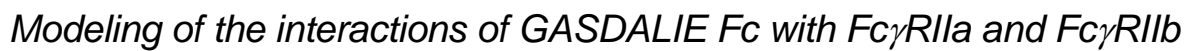

To gain understanding of the enhanced affinity of GASDALIE Fc for Fc $\gamma$ RIla compared to SDALIE Fc and to wtFc (GASDALIE Fc binds Fc $\gamma$ Rlla with 17-fold increased affinity compared with wtFc, whereas SDALIE Fc binds Fc $\gamma$ RIla with only 2-fold increased affinity compared with wtFc; Table 1 competition SPR results), we used homology modeling (Schrödinger, 2011) to create models of GASDALIE Fc:FcyRIla, and wtFc:Fc $\gamma$ Rlla complexes based on high-resolution structures of Fc $\gamma$ RIla (PDB 3RY4), the

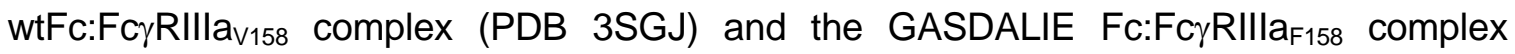


described in this study. We also created homology models of GASDALIE Fc:FcyRllb and wtFc:FcyRllb complexes using the FcyRllb structure (PDB 2FCB) to look for a structural rationalization for the relatively small effect of the GASDALIE substitutions on Fc binding

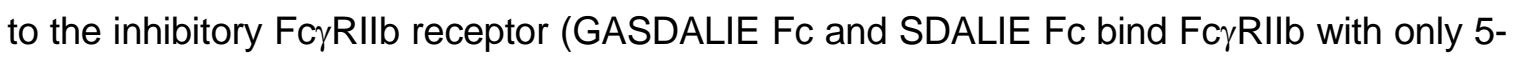
6-fold increased affinities compared with wtFc; Table 1 competition SPR results). The

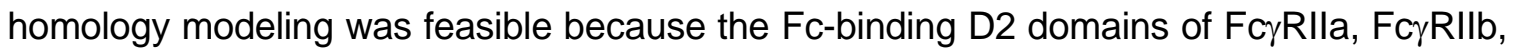
and FcyRllla share sequence and structural homology (root mean square deviations, rmsds, ranging from $0.5-0.7 \AA$ for pairwise combinations) (Fig. 3a,b) and bind to Fcs with similar orientations, as demonstrated by crystal structures (Ferrara et al., 2011; Maxwell et al., 1999; Mimoto et al., 2013; Mizushima et al., 2011; Radaev et al., 2001; Ramsland et al., 2011; Sondermann et al., 1999; Sondermann et al., 2000; Sondermann et al., 2001) and site-directed mutagenesis studies (Maxwell et al., 1999; Mimoto et al., 2013; Ramsland et al., 2011; Shields et al., 2001; Sondermann et al., 1999; Sondermann et al., 2001).

To validate the modeling methods, we first constructed a homology model of the

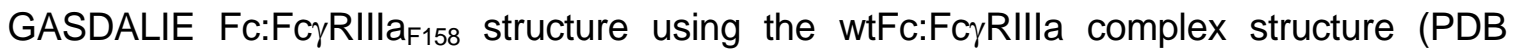
3SGJ) as a starting reference. The GASDALIE Fc:FcyRllla $\mathrm{F}_{158}$ model exhibited a $1.2 \AA$ rmsd compared with the GASDALIE Fc:Fc $\gamma \mathrm{RIII}_{\mathrm{F}_{158}}$ crystal structure (calculated for all $\mathrm{C} \alpha$ atoms) and reproduced the interactions of the GASDALIE substitutions with FcyRllla ${ }_{F 158}$. The relatively large rmsd for the superposition is explained by the flexibility and partial disorder of the D1 domain of FcyRllla, which does not contact Fc in Fc:FcyRIlla complex structures (Ferrara et al., 2011; Mizushima et al., 2011; Radaev et al., 2001; Sondermann et al., 2000) (Fig. 2a). By comparison, the D2 domain in the modeled GASDALIE

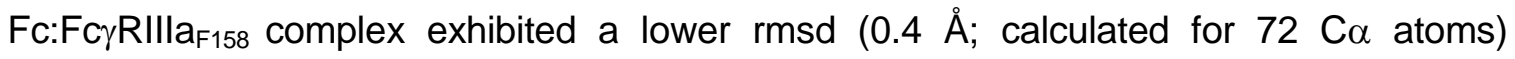
compared with the GASDALIE Fc:Fc $\gamma \mathrm{Rllla}_{\mathrm{F} 158}$ crystal structure. Having validated the 
homology modeling procedure, we generated homology models for GASDALIE Fc:Fc $\gamma R$ Illa, GASDALIE Fc:Fc $\gamma R I l b$, wtFc:Fc $\gamma R$ Ila, and wtFc:Fc $\gamma$ RIlb complex structures by aligning the D2 domain of $\mathrm{Fc \gamma R}$ Ila or $\mathrm{Fc} \gamma \mathrm{RIIb}$ with $\mathrm{D} 2$ of $\mathrm{Fc} \gamma \mathrm{R}$ Illa in the appropriate Fc:Fc $\gamma$ RIIla complex structure.

Several interactions predicted by the GASDALIE Fc:Fc $\gamma$ RIlla and wtFc:Fc $\gamma$ Rlla homology models gave insight into the 17-fold increased affinity of GASDALIE Fc versus wtFc for FcyRlla. On Fc chain A, Asp239 (SD in GASDALIE) and Asp265 were predicted to form electrostatic interactions with Fc $\gamma$ RIla Lys117 (the counterpart of Fc $\gamma$ RIIla Lys120) (Fig. 3c, top left). Fc residue Asp265 may also hydrogen bond with FcyRlla residue His131. By comparison, in the wtFc:Fc $\gamma$ Rlla structure, Fc residue 239, a serine, did not contact Fc $\gamma$ Rlla, although Fc residue Asp265 was predicted to form a salt bridge with FcyRlla Lys117 and a hydrogen bond with FcyRlla His131 (Fig. 3c, top right). Fc substitutions Leu330 and Glu332 (AL and IE in GASDALIE Fc) were not predicted to play a role in binding at the interface of Fc $\gamma$ RIla with GASDALIE Fc chain A. The effects of the GA substitution in GASDALIE Fc may be explained by a predicted hydrogen bond between GASDALIE Fc residue Ala236 (the site of the GA substitution) and FcyRlla residue His131, whereas Fc residue Gly236 in wtFc is not predicted to interact with the Fc $\gamma$ RIla (Fig. 3c). Consistent with the similar binding affinities of GASDALIE Fc and wtFc for FcyRllb (Table 1), the GASDALIE substitutions Ala236, Asp239, Leu330, and Glu332 in GASDALIE FC chain A were not predicted to play a role at the binding interface with Fc $\gamma$ RIlb in the GASDALIE Fc:Fc $\gamma R$ Illb homology model (Fig. 3c, bottom left). Although Fc $\gamma$ Rlla residue Lys117 was predicted to participate in electrostatic interactions and hydrogen bonding at the GASDALIE Fc:Fc $\gamma R$ Rlla interface, Lys117 of Fc $\gamma R$ Illb was not predicted to interact with any of the Fc residues on chain A of either GASDALIE Fc or wtFc (Fig. 3c, bottom). 
On Fc chain B, residues Asp239 (the SD substitution of GASDALIE) and Asp265 are predicted to hydrogen bond with FcyRlla residue Thr158 (Fig. 3d, top left). By comparison, if there is a serine instead of an aspartate at Fc position 239, as in wtFc, a hydrogen bond is predicted to form between the serine and FcyRlla residue Tyr157 (Fig. 3d, top right). The remaining GASDALIE substitutions (GA, AL, and IE substitutions) are not predicted to play a role at the interface in this region. In the GASDALIE Fc:Fc $\gamma R$ Illb model, Fc residue Ala236 (GA substitution) is predicted to hydrogen bond with FcyRllb residues Tyr160 and possible also Thr158 (Fig. 3d, bottom left). If there is a glycine at Fc position 236 instead of an alanine, as in the wtFc, a hydrogen bond is predicted to form with FcyRllb residue Tyr160 (Figure 3d, bottom right). Asp239, Leu330 and Glu332 (GASDALIE SD, AL, and IE substitutions) are not predicted to play a role at the GASDALIE chain B Fc interface with FcyRllb. Thus the GASDALIE Fc substitutions in Fc chain B do not exert major effects on interactions with Fc $\gamma R$ Rllb. The addition of the G236A mutation is predicted to result in an increase of hydrogen bonding at the GASDALIE Fc:Fc $\gamma R$ Illa interface but not at the GASDALIE Fc:Fc $\gamma R$ Illb interface, which may explain the 7-fold increase in affinity for Fc $\gamma$ Rlla of GASDALIE Fc when compared to SDALIE Fc, which lacks the GA substitution in GASDALIE Fc.

\section{Conformations of free and receptor-bound GASDALIE FC}

In order to determine if unbound GASDALIE Fc exhibits conformational changes associated with its increased affinity for $\mathrm{Fc}_{\mathrm{C}} \mathrm{R} / \mathrm{Ila}_{\mathrm{F} 158}$ compared with wtFc, we solved a 2.4 $\AA$ resolution crystal structure of GASDALIE Fc alone by molecular replacement $\left(R_{\text {cryst }}=\right.$ $\left.0.24 ; \mathrm{R}_{\text {free }}=0.26\right)$. The structure revealed a typical Fc homodimer with $\mathrm{N}$-glycans attached to $\mathrm{C}_{\mathrm{H}} 2$ domain residue Asn297. Ordered electron density was observed up to a terminal galactose on the 6-arm and up to a terminal $\mathrm{N}$-acetyl glucosamine on the 3-arm of the $\mathrm{N}$ - 
linked glycan, as found in wtFc structures and the SDALIE Fc structure (Oganesyan et al., 2008a). The SDALIE substitutions were located in ordered electron density; however, the region containing Ala236 (the GA substitution in GASDALIE) was disordered on both chains A and B (Supplementary Fig. 1d).

To assess potential differences between GASDALIE Fc and wtFc structures, the $\mathrm{C}_{\mathrm{H}} 3$ domains of each $\mathrm{FC}$ were aligned and the positions of the $\mathrm{C}_{\mathrm{H}} 2$ domains were compared (Figure 4a,b). We monitored $\mathrm{C}_{\mathrm{H}} 2$ domain separations in the various $\mathrm{Fc}$ structures by measuring distances between the $\mathrm{C} \alpha$ atoms at $\mathrm{C}_{\mathrm{H}} 2$ positions 238, 241, 301, and 329 as described (Ahmed et al., 2014; Teplyakov et al., 2013) (Figure 4c). As previously noted, wtFc structures exhibit relatively small structural differences, showing similar $\mathrm{C}_{\mathrm{H}} 2$ domain separations despite differences in crystal packing (Ahmed et al., 2014). The separation between the $\mathrm{C}_{\mathrm{H}} 2$ domains of GASDALIE FC structure fell within range of $\mathrm{C}_{\mathrm{H}} 2$ domain separations in wtFc (PDB 3DO3, 2DTS, 3AVE, 1HZH and 4Q7D); therefore the GASDALIE mutations did not greatly influence the overall $\mathrm{C}_{\mathrm{H}} 2-\mathrm{C}_{\mathrm{H}} 2$ domain arrangement in the unbound structure (Fig. 4a; Table 2). We also aligned the $\mathrm{C}_{\mathrm{H}} 3$ domains of the unbound GASDALIE FC structure with the $\mathrm{C}_{\mathrm{H}} 3$ domains of the $2.5 \AA$ SDALIE FC structure (PDB 2QL1) (Oganesyan et al., 2008a). SDALIE Fc was in a more open conformation than GASDALIE with an rmsd of $5.8 \AA$ calculated for the $201 \mathrm{C}_{\mathrm{H}} 2$ domain $\mathrm{C} \alpha$ atoms (Fig. 4a).

We next compared the free GASDALIE Fc structure to the structure of GASDALIE solved in complex with FcyRIIIa ${ }_{\mathrm{F} 158}$. No notable differences were seen in side chain conformations at the sites of the GASDALIE mutations (Supplementary Fig. 1c.d). The $\mathrm{C}_{\mathrm{H}} 2$ domains of the bound GASDALIE FC were in a more open conformation compared with the unbound form (Fig. 4b, Table 2) (rmsd of $2.3 \AA$ calculated for the $202 \mathrm{C} \alpha$ atoms of the $\mathrm{C}_{\mathrm{H}} 2$ domains of one $\mathrm{Fc}$ after alignment of the $\mathrm{C}_{\mathrm{H}} 3$ domains in each structure) and the 
FcyRlla ${ }_{F 158}$-bound GASDALIE Fc fell within the range of $\mathrm{C}_{\mathrm{H}} 2$ domain separations for receptor-bound Fc structures (Fig. 4b; Table 2). This result was expected since previously solved complexes of afucosylated and fucosylated Fc bound to FcyRllla did not show major changes in overall Fc conformation (Ferrara et al., 2011; Sondermann et al., 2000).

\section{Discussion}

The effector functions of $\operatorname{lgG}$ can be modulated with glycan and protein modifications to its Fc region (Ackerman and Nimmerjahn, 2014). Here we examined the effects of introducing amino acid substitutions in the $\mathrm{FC}_{\mathrm{H}_{2}} 2$ domain, either G236A/S239D/A330L/I332E (GASDALIE) or S239D/A330L/I332E (SDALIE), which increase binding to activating $\mathrm{F} \gamma \mathrm{R}$ receptors but exhibit relatively small affinity increases for the FcyRllb inhibitory receptor (Bournazos et al., 2014a; Bournazos et al., 2014b) (Table 1). These effects lead to enhanced Fc-mediated effector functions, of importance for the efficacies of therapeutic antibodies against cancer and infectious diseases (Ferrara et al., 2011; Lazar et al., 2006; Matsumiya et al., 2007; Mizushima et al., 2011; Richards et al., 2008).

Previous SPR-based measurements to derive affinities of wtFc and mutant Fcs for FcyRs used a 1:1 (Langmuir) binding model to derive kinetic constants for the interactions of Fc proteins with immobilized receptors (Bournazos et al., 2014b; Lazar et al., 2006; Richards et al., 2008; Smith et al., 2012). Here we showed that sensorgrams of Fc binding to immobilized FcrRs do not fit a 1:1 binding model, and are therefore unlikely to result in reliable binding affinity constants (Fig. 1a). In order to avoid inaccuracies resulting from poorly fit models of Fc binding to immobilized receptors, we chose a measurement method based on equilibrium binding in solution to derive affinities for Fcy $\mathrm{Rs}$ binding to the GASDALIE and SDALIE FCS (Fig. 1b). The method is based on concentration 
measurements of unbound ligands after equilibrium binding to their binding partner (Nieba et al., 1996); in this case, Fc binding to an Fc $\gamma \mathrm{R}$. Concentrations of free ligand were determined using a calibration measurement series carried out in the same experiment. Using this method, we found that GASDALIE FC and SDALIE Fc showed over two orders of magnitude of enhanced binding compared with wtFc to the activating Fc receptor Fc $\gamma R$ RIIla $\mathrm{F}_{158}$, but only a 5-6-fold increase in binding to the inhibitory receptor Fc $\gamma \mathrm{RIIb}$. GASDALIE FC also exhibited increased binding (17-fold higher affinity) to FcyRlla, whereas the affinities of SDALIE Fc and wtFc for Fc $\gamma$ RIla were similar (Table 1). Although our structural studies showed that the G236A substitution that distinguishes GASDALIE and SDALIE formed a hydrophobic contact with residue Phe158 of FCyRIIla ${ }_{F 158}$ in the

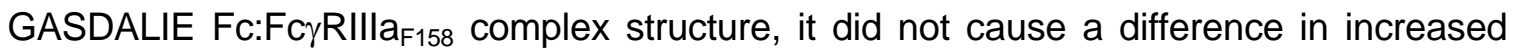
binding affinity between SDALIE Fc and GASDALIE Fc to Fc $\gamma \mathrm{RIIIa}_{\mathrm{F} 158}$ when compared to wtFc (Fig. 2; Table 1); however, homology modeling of a GASDALIE Fc:Fc $\gamma$ Rlla complex suggested that GASDALIE Fc residue Ala236 could enhance binding of GASDALIE Fc to Fc $\gamma R$ Illa through increased $\mathrm{H}$-bond interactions as compared with binding of SDALIE and wtFc (Fig. 3).

We used the GASDALIE Fc:Fc $\gamma R$ IIIIa ${ }_{\text {F158 }}$ complex crystal structure to rationalize the increased affinities for activating Fc $\gamma$ Rs resulting from the GASDALIE substitutions. The structure revealed electrostatic interactions resulting from the interactions of negative charges introduced by the SD and IE GASDALIE substitutions with lysine residues in the receptor; e.g., the side chain of Fc $\gamma$ RIIla Lys120 extended into a pocket on Fc containing chain A residues Asp265 and Asp239 (SD in GASDALIE). Although not one of the GASDALIE substitutions, Fc residue Asp265 is important for interactions with Fc $\gamma$ Rs to mediate ADCC: when this residue was substituted for alanine, binding to both activating and inhibitory Fc $\gamma$ Rs was abrogated (DiLillo et al., 2014). The introduction of Asp239 (SD 
in GASDALIE and SDALIE) may further stabilize the Asp265 $\mathrm{Fd}_{\mathrm{d}}$ Lys120 $\mathrm{FcyR}_{\mathrm{R}}$ interaction contributing to the higher than wtFc affinities of GASDALIE and SDALIE Fcs for Fc $\gamma$ RIlla. Fc $\gamma$ Rlla also includes a lysine at position 120 predicted to form similar electrostatic interactions with Fc chain A Asp239 leading to an enhanced binding to activating FcyRs. Another receptor lysine, Lys $161_{\text {FcyRllla }}$, formed an electrostatic interaction with GASDALIE Fc residue Glu332 (the IE portion of the GASDALIE substitutions), which cannot occur in wtFc containing an isoleucine at position 332. The greater increase in electrostatic interactions at the interface of GASDALIE Fc with FcrRIlla $\mathrm{F}_{158}$ (GASDALIE Asp239 interactions with $\mathrm{Fc}_{\gamma} \mathrm{RIII} \mathrm{a}_{\mathrm{F} 158}$ Lys120 and GASDALIE Glu332 interactions with $\mathrm{Fc}_{\mathrm{R}} \mathrm{RIII \textrm {a } _ { \mathrm { F } 1 5 8 }}$ Lys161) and FcyRlla (GASDALIE Asp239 interactions with FcyRlla Lys120) suggests that electrostatic interactions with receptor lysines are the main contributors in enhancement of

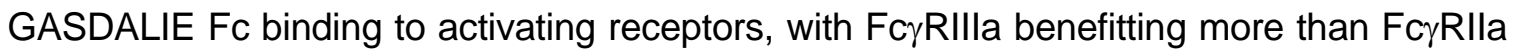
from the SD and IE substitutions of GASDALIE Fc.

We also present the structures of GASDALIE Fc in its unbound state. Fc structures exhibit varying degrees of openness, as assessed by the separation of their $\mathrm{C}_{\mathrm{H}} 2$ domains (Ahmed et al., 2014; Ferrara et al., 2011; Mizushima et al., 2011; Oganesyan et al., 2008a; Radaev et al., 2001; Sondermann et al., 2001), although wtFc structures are relatively similar to each other (Ahmed et al., 2014). The GASDALIE Fc structure was similar to wtFc structures in that the separation of its $\mathrm{C}_{\mathrm{H}} 2$ domains fell within the range of $\mathrm{C}_{\mathrm{H}} 2$ domain separations in wtFc structures (Fig. 4A; Table 2). By contrast, the SDALIE Fc structure was in a more open conformation than wtFc structures (Oganesyan et al., 2008a). However, notable changes in the side chain conformations of the SDALIE substitutions were not observed when compared to GASDALIE Fc. 


\section{Conclusions}

Here we present binding and structural data relevant to understanding the effects of the GASDALIE substitutions in Fc for its interactions with FcyRs. We found that both GASDALIE and SDALIE Fcs exhibited large increases in binding to activating Fc $\gamma$ Rs, most notably to FcyRIIla. This property, when combined with their relatively small effects on binding to the inhibitory Fc $\gamma \mathrm{R}$ Ilb receptor, is optimal for eliciting activation of Fc $\gamma \mathrm{R}$ IIla- and Fc $\gamma$ Rlla-expressing cells leading to ADCC. Further co-crystallization experiments with both Fc $\gamma$ RIla and FcyRllb and binding experiments with other Fc variants will be essential for further understanding how these mutations allow selection for activating Fc receptors.

\section{Acknowledgements}

We thank Stylianos Bournazos, John Desjarlais, and Jeffrey Ravetch for helpful discussions, the Caltech Protein Expression Center for protein production, members of the Bjorkman lab for critical reading of the manuscript, Marta Murphy for help making figures, and Jens Kaiser and members of the staff at the Advanced Light Source (ALS) for help with data collection and processing. The Advanced Light Source is supported by the Director, Office of Science, Office of Basic Energy Sciences, of the U.S. Department of Energy under Contract No. DE-AC02-05CH11231. This research was supported by the National Institute Of Allergy And Infectious Diseases of the National Institutes of Health Grant HIVRAD P01 Al100148 (P.J.B.); (the content is solely the responsibility of the

authors and does not necessarily represent the official views of the National Institutes of Health) and the Molecular Observatory at Caltech supported by the Gordon and Betty Moore Foundation.

\section{Accession numbers}

Atomic coordinates and structure factors have been deposited in the PDB with accession codes 5D4Q (GASDALIE Fc) and 5D6D (GASDALIE Fc:Fc $\gamma R$ RIIIa) 


\begin{tabular}{|c|c|c|c|c|c|c|c|c|c|c|}
\hline IgG Variant & Detection Method & $\begin{array}{l}\text { FcyRIIla } \\
K_{\mathrm{D}}(\mathrm{nM}) \\
\end{array}$ & Variant & $\begin{array}{c}\text { Fold } \\
\text { improved } \\
\text { affinity } \\
\text { compared } \\
\text { with wtFc } \\
\end{array}$ & $\begin{array}{l}\text { FcyRlla } \\
K_{\mathrm{D}}(\mathrm{nM}) \\
\end{array}$ & Variant & $\begin{array}{c}\text { Fold } \\
\text { improved } \\
\text { affinity } \\
\text { compared } \\
\text { with wtFc } \\
\end{array}$ & $\begin{array}{l}\text { FcyRllb } \\
K_{\mathrm{D}}(\mathrm{nM}) \\
\end{array}$ & $\begin{array}{c}\text { Fold } \\
\text { improved } \\
\text { affinity } \\
\text { compared } \\
\text { with wtFc } \\
\end{array}$ & Reference \\
\hline \multirow[t]{11}{*}{ wtFc (IgG1) } & $\begin{array}{c}\text { Conventional SPR } \\
\text { (FcR surface) }\end{array}$ & 2950 & F158 & & 1380 & $\mathrm{H} 131$ & & 2520 & & $\begin{array}{c}\text { Smith et al., } \\
2012\end{array}$ \\
\hline & $\begin{array}{l}\text { Conventional SPR } \\
\text { (FCR surface) }\end{array}$ & 432 & V158 & & 1550 & $\mathrm{R} 131$ & & & & $\begin{array}{c}\text { Smith et al., } \\
2012\end{array}$ \\
\hline & $\begin{array}{l}\text { Conventional SPR } \\
\text { (FcR surface) }\end{array}$ & 2220 & F158 & & 1330 & $\mathrm{R} 131$ & & 2700 & & $\begin{array}{l}\text { Bournazos } \\
\text { et al., 2014a }\end{array}$ \\
\hline & $\begin{array}{c}\text { Conventional SPR } \\
\text { (FcR surface) }\end{array}$ & 2200 & F158 & & 1400 & $\mathrm{H} 131$ & & 2400 & & $\begin{array}{l}\text { Bournazos } \\
\text { et al., 2014b }\end{array}$ \\
\hline & $\begin{array}{c}\text { Conventional SPR } \\
\text { (FcR surface) }\end{array}$ & 410 & V158 & & 1500 & $\mathrm{R} 131$ & & & & $\begin{array}{l}\text { Bournazos } \\
\text { et al., } 2014 \mathrm{~b}\end{array}$ \\
\hline & $\begin{array}{c}\text { Conventional SPR } \\
\text { (FcR surface) }\end{array}$ & 2950 & F158 & & 1550 & $\mathrm{R} 131$ & & 2520 & & $\begin{array}{l}\text { DiLillo et al., } \\
2015\end{array}$ \\
\hline & $?$ & 2000 & $?$ & & 500 & $?$ & & 500 & & $\begin{array}{l}\text { Janeway et } \\
\text { al., } 2005\end{array}$ \\
\hline & $\begin{array}{c}\text { Conventional SPR } \\
\text { (FcR surface) }\end{array}$ & 854 & F158 & & 192 & $\mathrm{H} 131$ & & 8333 & & $\begin{array}{c}\text { Bruhns et al., } \\
2009\end{array}$ \\
\hline & $\begin{array}{c}\text { Conventional SPR } \\
\text { (FCR surface) }\end{array}$ & 500 & V158 & & 286 & R131 & & & & $\begin{array}{c}\text { Bruhns et al., } \\
2009\end{array}$ \\
\hline & $\begin{array}{l}\text { Competition SPR } \\
\text { (FcR surface) }\end{array}$ & 252 & V158 & & & & & & & $\begin{array}{l}\text { Lazar et al., } \\
2006\end{array}$ \\
\hline & $\begin{array}{c}\text { Conventional SPR } \\
\text { (FcR surface) }\end{array}$ & 4454 & F158 & & 4486 & $\mathrm{H} 131$ & & 9275 & & $\begin{array}{c}\text { current } \\
\text { publication }\end{array}$ \\
\hline \multirow[t]{2}{*}{ SDALIE Fc } & $\begin{array}{c}\text { Conventional SPR } \\
\text { (FcR surface) }\end{array}$ & 201 & F158 & 22 & 1487 & $\mathrm{H} 131$ & 3 & 2193 & 4 & $\begin{array}{c}\text { current } \\
\text { publication }\end{array}$ \\
\hline & $\begin{array}{l}\text { Competition SPR } \\
\text { (FcR surface) }\end{array}$ & -- & F158 & 318 & -- & $\mathrm{H} 131$ & 2 & -- & 5 & $\begin{array}{c}\text { current } \\
\text { publication }\end{array}$ \\
\hline \multirow[t]{8}{*}{$\begin{array}{c}\text { GASDALIE } \\
\text { FC } \\
\end{array}$} & $\begin{array}{c}\text { Conventional SPR } \\
\text { (FcR surface) }\end{array}$ & 100 & F158 & 30 & 82 & $\mathrm{H} 131$ & 17 & 736 & 3 & $\begin{array}{c}\text { Smith et al., } \\
2012 \\
\end{array}$ \\
\hline & & 124 & V158 & 3 & 63 & $\mathrm{R} 131$ & 25 & & & $\begin{array}{c}\text { Smith et al., } \\
2012\end{array}$ \\
\hline & $\begin{array}{c}\text { Conventional SPR } \\
\text { (FcR surface) }\end{array}$ & 144 & F158 & 15 & 104 & $\mathrm{R} 131$ & 13 & 1670 & 2 & $\begin{array}{c}\text { Bournazos } \\
\text { et al., 2014a }\end{array}$ \\
\hline & $\begin{array}{l}\text { Conventional SPR } \\
\text { (FcR surface) }\end{array}$ & 110 & F158 & 20 & 82 & $\mathrm{H} 131$ & 17 & 1500 & 2 & $\begin{array}{l}\text { Bournazos } \\
\text { et al., 2014b }\end{array}$ \\
\hline & $\begin{array}{c}\text { Conventional SPR } \\
\text { (FcR surface) }\end{array}$ & 100 & V158 & 4 & 120 & $\mathrm{R} 131$ & 13 & & & $\begin{array}{l}\text { Bournazos } \\
\text { et al., 2014b }\end{array}$ \\
\hline & $\begin{array}{c}\text { Conventional SPR } \\
\text { (FCR surface) }\end{array}$ & 100 & F158 & 30 & 63 & $\mathrm{R} 131$ & 25 & 736 & 3 & $\begin{array}{l}\text { DiLillo et al., } \\
2015\end{array}$ \\
\hline & $\begin{array}{c}\text { Conventional SPR } \\
\text { (FcR surface) }\end{array}$ & 213 & F158 & 21 & 1585 & $\mathrm{H} 131$ & 3 & 3882 & 2 & $\begin{array}{c}\text { current } \\
\text { publication }\end{array}$ \\
\hline & $\begin{array}{c}\text { Competition SPR } \\
\text { (FcR surface) }\end{array}$ & -- & F158 & 431 & -- & $\mathrm{H} 131$ & 17 & -- & 6 & $\begin{array}{c}\text { current } \\
\text { publication }\end{array}$ \\
\hline
\end{tabular}

Table 1. Comparison of Fc:Fc $\gamma R$ affinities 


\begin{tabular}{|c|c|c|c|c|c|c|c|c|}
\hline PDB & Protein & $\begin{array}{c}\text { Resolution } \\
(\AA) \\
\end{array}$ & $\begin{array}{l}\text { Space } \\
\text { group }\end{array}$ & $\begin{array}{c}\text { Unit cell } \\
\mathbf{a}, \mathbf{b}, \mathbf{c}(\AA) \\
\alpha, \beta, \gamma\left({ }^{\circ}\right) \\
\end{array}$ & $\begin{array}{c}\text { Pro238 } \\
(\AA) \\
\end{array}$ & $\begin{array}{c}\text { Phe241 } \\
(\AA) \\
\end{array}$ & $\begin{array}{c}\text { Arg301 } \\
(\AA)\end{array}$ & $\begin{array}{c}\text { Pro329 } \\
(\AA) \\
\end{array}$ \\
\hline 5D4Q & GASDALIE FC & 2.4 & $\mathrm{P} 22_{1} 2_{1} 2_{1}$ & $\begin{array}{c}49,79,138 \\
90,90,90 \\
\end{array}$ & 19 & 22 & 33 & 24 \\
\hline 2QL1 & SDALIE FC & 2.5 & $\mathrm{C} 222_{1}$ & $\begin{array}{c}50,149,76 \\
90,90,90 \\
\end{array}$ & 28 & 29 & 37 & 39 \\
\hline 5D6D & $\begin{array}{l}\text { GASDALIE Fc: } \\
\text { FcyRIIla } \\
\end{array}$ & 3.1 & $\mathrm{P} 22_{1} 2_{1}$ & $\begin{array}{c}74,95,108 \\
90,90,90 \\
\end{array}$ & 25 & 25 & 38 & 31 \\
\hline 3SGJ & $\begin{array}{c}\text { afucosylated Fc: } \\
\text { FcyRllla }\end{array}$ & 2.2 & $\mathrm{P} 22_{1} 2_{1}$ & $\begin{array}{c}67,89,140 \\
90,90,90 \\
\end{array}$ & 26 & 26 & 37 & 32 \\
\hline 3SGK & $\begin{array}{c}\text { fucosylated Fc: } \\
\text { FcyRIlla } \\
\end{array}$ & 2.4 & $\mathrm{P} 22_{1} 2_{1} 2_{1}$ & $\begin{array}{c}67,88,141 \\
90,90,90 \\
\end{array}$ & 26 & 27 & 37 & 33 \\
\hline 3AY4 & $\begin{array}{c}\text { afucosylated Fc: } \\
\text { FcyRIIla } \\
\end{array}$ & 2.2 & $\mathrm{P} 4_{1} 2_{1} 2$ & $\begin{array}{l}77,77,350 \\
90,90,90 \\
\end{array}$ & 25 & 26 & 37 & 31 \\
\hline 1E4K & $\begin{array}{c}\text { fucosylated Fc: } \\
\text { FcyRIIlb }\end{array}$ & 3.2 & $\mathrm{P}_{5} 22$ & $\begin{array}{c}115,115,299 \\
90,90,120 \\
\end{array}$ & 25 & 26 & 37 & 30 \\
\hline $1 \mathrm{~T} 89$ & $\begin{array}{c}\text { fucosylated Fc: } \\
\text { FcyRIIIb } \\
\end{array}$ & 3.5 & $\mathrm{P}_{5} 22$ & $\begin{array}{c}115,115,301 \\
90,90,120 \\
\end{array}$ & 25 & 26 & 37 & 31 \\
\hline $1 \mathrm{~T} 83$ & $\begin{array}{c}\text { fucosylated Fc: } \\
\text { FcyRIIllb }\end{array}$ & 3.0 & $\mathrm{P} 22_{1} 2_{1} 2_{1}$ & $\begin{array}{c}73,102,123 \\
90,90,90\end{array}$ & 25 & 26 & 37 & 31 \\
\hline
\end{tabular}

Table 2. Comparison of $\mathrm{C}_{\mathrm{H}} 2$ domain separation in Fc structures 


\section{FIGURE LEGENDS}

Figure 1. SPR binding assays of Fc:Fc $\gamma R$ interactions. (a) Sensorgrams from conventional SPR experiments in which Fc proteins were injected over immobilized FcyRs. Experimental data (colored lines) were fit to a 1:1 binding model (black lines). Residual plots are shown below each set of sensorgrams. For most interactions, the association and/or dissociation phases of the sensorgrams do not fit a 1:1 binding model. In cases in which the association and dissociation rates are very fast, the 1:1 binding model appears to fit the sensorgrams, but the kinetic rate constants are outside of the detectable range of the instrument and the equilibrium $\mathrm{RU}$ values do not converge as the concentration of analyte is raised. (b) Competition SPR results. Equilibrium binding curves for interactions of the Fc variants (wtFc, SDALIE Fc, and GASDALIE Fc) with Fcy receptors (FcyRIIIa, FcyRlla, and FcyRllb). Each curve represents an equilibrium binding experiment in which the free Fc concentration (y-axis) is plotted versus the competitor (FcyR) concentration (logarithmic $\mathrm{x}$-axis). Data points (triangles, circles, or squares) were fit by non-linear regression to the second order root function to an equilibrium binding model (solid black line) as described in the Methods. The more a curve is shifted to the left, the stronger the Fc:FcyR binding (i.e., the higher the affinity).

Figure 2. Structure of GASDALIE Fc:Fc $\gamma R$ IIIIa $_{F_{158}}$ complex. (a) Overview of the GASDALIE Fc:Fc $\gamma R R_{I I l a} F_{158}$ complex. Fc $\gamma R$ IIIa $_{F 158}$ is in pink ribbon representation and GASDALIE Fc is in blue ribbon representation with the G236/S239D/A330L/I332E mutations highlighted as red spheres and $\mathrm{N}$-linked glycans shown as blue sticks. (b-c) Comparison of interfaces in

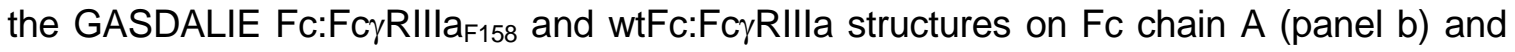
Fc chain B (panel c). Residues involved in interactions are shown in magenta (FcyRIIla) 
and blue $(\mathrm{Fc})$ with oxygen atoms in red and nitrogens in blue. Dotted lines between atoms represent lectrostatic interactions (red) or hydrogen bonds (yellow). Residues that do not participate in hydrogen bonds or electrostatic interactions are shown in gray.

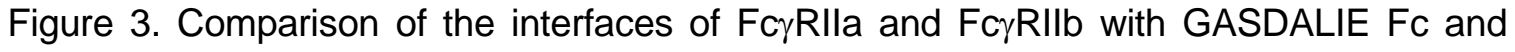
wtFc using homology modeling. (a) Alignment of the D2 domains of FcyRlla (PDB 3RY4,

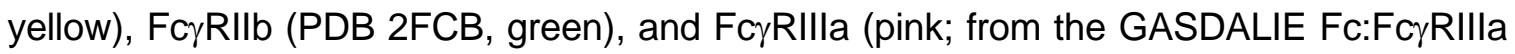
complex structure). (b) Sequence alignment of the D1 and D2 domains of Fc $\gamma$ Rlla, Fc $\gamma$ Rllb and FcyRllla. Identical residues are highlighted in green and similar residues are highlighted in gray. (c-d) Homology modeled interfaces of GASDALIE Fc and wtFc with

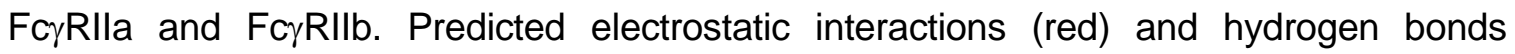
(yellow) are shown as dashes. Residues that are not predicted to participate in the Fc:FcgR interfaces are shown in gray. (c) Interactions of chain A of GASDALIE Fc (left)

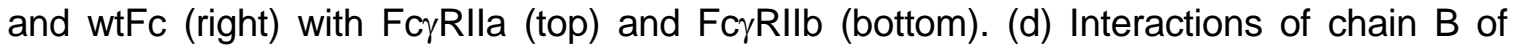

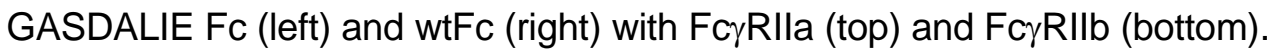

Figure 4. Structure of unbound GASDALIE Fc. (a) Comparison of structures of unbound GASDALIE Fc (cyan), SDALIE Fc (blue; PDB 2QL1), and wtFc (gray; PDB IDs: 3DO3, 2DTS, 3AVE, 4Q7D, 1HZH) after alignment of $\mathrm{C}_{\mathrm{H}} 3$ domains. (b) Comparison of unbound GASDALIE Fc (cyan), FcyRllla-bound GASDALIE Fc (blue-gray), and SDALIE Fc (blue) after alignment of $\mathrm{C}_{H} 3$ domains. (c) wtFc structure (PDB: 3AVE) showing location of $\mathrm{C} \alpha$ atoms for Pro238, Phe241, Arg301, and Pro329 (red spheres) used for $\mathrm{C}_{\mathrm{H}} 2$ domain separation distance measurements. $\mathrm{C}_{\mathrm{H}} 2$ domain separations in individual $\mathrm{Fc}$ structures in Table 2 were evaluated by measuring distances (dotted lines) between the corresponding 
red spheres on each chain. C $\alpha$ atoms for Asn297 (site of $N$-glycan attachment) indicated as blue spheres.

\section{REFERENCES}

Ackerman, M.E., and Nimmerjahn, F. (2014). Antibody Fc linking adaptive and innate immunity (Amsterdam ; Burlington: Elsevier Science,), pp. 1 online resource (xii, 363 pages).

Adams, P.D., Afonine, P.V., Bunkoczi, G., Chen, V.B., Davis, I.W., Echols, N., Headd, J.J., Hung, L.W., Kapral, G.J., Grosse-Kunstleve, R.W., et al. (2010). PHENIX: a comprehensive Python-based system for macromolecular structure solution. Acta Crystallogr D Biol Crystallogr 66, 213-221.

Ahmed, A.A., Giddens, J., Pincetic, A., Lomino, J.V., Ravetch, J.V., Wang, L.X., and Bjorkman, P.J. (2014). Structural characterization of anti-inflammatory immunoglobulin $G$ Fc proteins. Journal of molecular biology 426, 3166-3179.

Anthony, R.M., Kobayashi, T., Wermeling, F., and Ravetch, J.V. (2011). Intravenous gammaglobulin suppresses inflammation through a novel $\mathrm{T}(\mathrm{H}) 2$ pathway. Nature 475 , 110-113.

Anthony, R.M., Nimmerjahn, F., Ashline, D.J., Reinhold, V.N., Paulson, J.C., and Ravetch, J.V. (2008a). Recapitulation of IVIG anti-inflammatory activity with a recombinant IgG Fc. Science 320, 373-376.

Anthony, R.M., and Ravetch, J.V. (2010). A novel role for the IgG Fc glycan: the antiinflammatory activity of sialylated IgG Fcs. J Clin Immunol 30 Suppl 1, S9-14.

Anthony, R.M., Wermeling, F., Karlsson, M.C., and Ravetch, J.V. (2008b). Identification of a receptor required for the anti-inflammatory activity of IVIG. Proc Natl Acad Sci U S A $105,19571-19578$.

Arnold, J.N., Wormald, M.R., Sim, R.B., Rudd, P.M., and Dwek, R.A. (2007). The impact of glycosylation on the biological function and structure of human immunoglobulins. Annual review of immunology 25, 21-50.

Bournazos, S., Chow, S.K., Abboud, N., Casadevall, A., and Ravetch, J.V. (2014a). Human IgG Fc domain engineering enhances antitoxin neutralizing antibody activity. The Journal of clinical investigation 124, 725-729. 
Bournazos, S., Klein, F., Pietzsch, J., Seaman, M.S., Nussenzweig, M.C., and Ravetch, J.V. (2014b). Broadly neutralizing anti-HIV-1 antibodies require Fc effector functions for in vivo activity. Cell 158, 1243-1253.

Bruhns, P., lannascoli, B., England, P., Mancardi, D.A., Fernandez, N., Jorieux, S., and Daeron, M. (2009). Specificity and affinity of human Fcgamma receptors and their polymorphic variants for human IgG subclasses. Blood 113, 3716-3725.

Burmeister, W.P., Huber, A.H., and Bjorkman, P.J. (1994). Crystal structure of the complex of rat neonatal Fc receptor with Fc. Nature 372, 379-383.

Butler, M., Quelhas, D., Critchley, A.J., Carchon, H., Hebestreit, H.F., Hibbert, R.G., Vilarinho, L., Teles, E., Matthijs, G., Schollen, E., et al. (2003). Detailed glycan analysis of serum glycoproteins of patients with congenital disorders of glycosylation indicates the specific defective glycan processing step and provides an insight into pathogenesis. Glycobiology 13, 601-622.

DiLillo, D.J., and Ravetch, J.V. (2015a). Differential Fc-Receptor Engagement Drives an Anti-tumor Vaccinal Effect. Cell 161, 1035-1045.

DiLillo, D.J., and Ravetch, J.V. (2015b). Fc-Receptor Interactions Regulate Both Cytotoxic and Immunomodulatory Therapeutic Antibody Effector Functions. Cancer Immunol Res 3, 704-713.

DiLillo, D.J., Tan, G.S., Palese, P., and Ravetch, J.V. (2014). Broadly neutralizing hemagglutinin stalk-specific antibodies require FcgammaR interactions for protection against influenza virus in vivo. Nat Med 20, 143-151.

Diskin, R., Marcovecchio, P.M., and Bjorkman, P.J. (2010). Structure of a clade C HIV-1 gp120 bound to CD4 and CD4-induced antibody reveals anti-CD4 polyreactivity. Nat Struct Mol Biol 17, 608-613.

Duncan, A.R., Woof, J.M., Partridge, L.J., Burton, D.R., and Winter, G. (1988). Localization of the binding site for the human high-affinity Fc receptor on IgG. Nature 332, 563-564.

Edberg, J.C., and Kimberly, R.P. (1997). Cell type-specific glycoforms of Fc gamma RIIla (CD16): differential ligand binding. Journal of immunology 159, 3849-3857.

Emsley, P., Lohkamp, B., Scott, W.G., and Cowtan, K. (2010). Features and development of Coot. Acta Crystallogr D Biol Crystallogr 66, 486-501.

Evans, P. (2006). Scaling and assessment of data quality. Acta Crystallogr D Biol Crystallogr 62, 72-82.

Evans, P.R. (2011). An introduction to data reduction: space-group determination, scaling and intensity statistics. Acta crystallographica Section D, Biological crystallography $67,282-292$.

Ferrara, C., Grau, S., Jager, C., Sondermann, P., Brunker, P., Waldhauer, I., Hennig, M., Ruf, A., Rufer, A.C., Stihle, M., et al. (2011). Unique carbohydrate-carbohydrate 
interactions are required for high affinity binding between FcgammaRIII and antibodies lacking core fucose. Proceedings of the National Academy of Sciences of the United States of America 108, 12669-12674.

Ferrara, C., Stuart, F., Sondermann, P., Brunker, P., and Umana, P. (2006). The carbohydrate at FcgammaRIIla Asn-162. An element required for high affinity binding to non-fucosylated IgG glycoforms. The Journal of biological chemistry $281,5032-5036$.

Hulett, M.D., and Hogarth, P.M. (1994). Molecular basis of Fc receptor function. Advances in immunology 57, 1-127.

Janeway, C.A., Travers, P., Walport, M., and Schlomchik, M.J. (2005). Immunobiology, 6th edn (New York, NY: Garland Science Publishing).

Kaneko, Y., Nimmerjahn, F., and Ravetch, J.V. (2006). Anti-inflammatory activity of immunoglobulin G resulting from Fc sialylation. Science 313, 670-673.

Karplus, P.A., and Diederichs, K. (2012). Linking crystallographic model and data quality. Science 336, 1030-1033.

Krissinel, E., and Henrick, K. (2007). Inference of macromolecular assemblies from crystalline state. J Mol Biol 372, 774-797.

Lazar, G.A., Dang, W., Karki, S., Vafa, O., Peng, J.S., Hyun, L., Chan, C., Chung, H.S., Eivazi, A., Yoder, S.C., et al. (2006). Engineered antibody Fc variants with enhanced effector function. Proceedings of the National Academy of Sciences of the United States of America 103, 4005-4010.

Leslie, A.G.W., and Powell, H.R. (2007). Processing DIffraction Data with Mosfilm. In Evolving Methods for Macromolecular Crystallography, pp. 41-51.

Lin, C.W., Tsai, M.H., Li, S.T., Tsai, T.I., Chu, K.C., Liu, Y.C., Lai, M.Y., Wu, C.Y., Tseng, Y.C., Shivatare, S.S., et al. (2015). A common glycan structure on immunoglobulin $\mathrm{G}$ for enhancement of effector functions. Proceedings of the National Academy of Sciences of the United States of America.

Matsumiya, S., Yamaguchi, Y., Saito, J., Nagano, M., Sasakawa, H., Otaki, S., Satoh, M., Shitara, K., and Kato, K. (2007). Structural comparison of fucosylated and nonfucosylated Fc fragments of human immunoglobulin G1. J Mol Biol 368, 767-779.

Maxwell, K.F., Powell, M.S., Hulett, M.D., Barton, P.A., McKenzie, I.F., Garrett, T.P., and Hogarth, P.M. (1999). Crystal structure of the human leukocyte Fc receptor, Fc gammaRIla. Nature structural biology 6, 437-442.

McCoy, A.J., Grosse-Kunstleve, R.W., Adams, P.D., Winn, M.D., Storoni, L.C., and Read, R.J. (2007). Phaser crystallographic software. J Appl Crystallogr 40, 658-674.

Mimoto, F., Katada, H., Kadono, S., Igawa, T., Kuramochi, T., Muraoka, M., Wada, Y., Haraya, K., Miyazaki, T., and Hattori, K. (2013). Engineered antibody Fc variant with selectively enhanced FcgammaRIlb binding over both FcgammaRIla(R131) and FcgammaRIla(H131). Protein engineering, design \& selection : PEDS 26, 589-598. 
Mizushima, T., Yagi, H., Takemoto, E., Shibata-Koyama, M., Isoda, Y., lida, S., Masuda, K., Satoh, M., and Kato, K. (2011). Structural basis for improved efficacy of therapeutic antibodies on defucosylation of their Fc glycans. Genes to cells : devoted to molecular \& cellular mechanisms 16, 1071-1080.

Nieba, L., Krebber, A., and Pluckthun, A. (1996). Competition BIAcore for measuring true affinities: large differences from values determined from binding kinetics. Anal Biochem 234, 155-165.

Nimmerjahn, F., and Ravetch, J.V. (2008). Anti-inflammatory actions of intravenous immunoglobulin. Annu Rev Immunol 26, 513-533.

Oganesyan, V., Damschroder, M.M., Leach, W., Wu, H., and Dall'Acqua, W.F. (2008a). Structural characterization of a mutated, ADCC-enhanced human Fc fragment. Molecular immunology 45, 1872-1882.

Oganesyan, V., Gao, C., Shirinian, L., Wu, H., and Dall'Acqua, W.F. (2008b). Structural characterization of a human Fc fragment engineered for lack of effector functions. Acta Crystallogr D Biol Crystallogr 64, 700-704.

Okazaki, A., Shoji-Hosaka, E., Nakamura, K., Wakitani, M., Uchida, K., Kakita, S., Tsumoto, K., Kumagai, I., and Shitara, K. (2004). Fucose depletion from human IgG1 oligosaccharide enhances binding enthalpy and association rate between IgG1 and FcgammaRIIla. J Mol Biol 336, 1239-1249.

Radaev, S., Motyka, S., Fridman, W.H., Sautes-Fridman, C., and Sun, P.D. (2001). The structure of a human type III Fcgamma receptor in complex with Fc. The Journal of biological chemistry 276, 16469-16477.

Ramsland, P.A., Farrugia, W., Bradford, T.M., Sardjono, C.T., Esparon, S., Trist, H.M., Powell, M.S., Tan, P.S., Cendron, A.C., Wines, B.D., et al. (2011). Structural basis for Fc gammaRIla recognition of human IgG and formation of inflammatory signaling complexes. Journal of immunology 187, 3208-3217.

Ravetch, J.V., and Bolland, S. (2001). IgG Fc receptors. Annual review of immunology 19, 275-290.

Ravetch, J.V., and Kinet, J.P. (1991). Fc receptors. Annual review of immunology 9, 457-492.

Richards, J.O., Karki, S., Lazar, G.A., Chen, H., Dang, W., and Desjarlais, J.R. (2008). Optimization of antibody binding to FcgammaRlla enhances macrophage phagocytosis of tumor cells. Molecular cancer therapeutics 7, 2517-2527.

Samuelsson, A., Towers, T.L., and Ravetch, J.V. (2001). Anti-inflammatory activity of IVIG mediated through the inhibitory Fc receptor. Science 291, 484-486.

Sazinsky, S.L., Ott, R.G., Silver, N.W., Tidor, B., Ravetch, J.V., and Wittrup, K.D. (2008). Aglycosylated immunoglobulin $\mathrm{G} 1$ variants productively engage activating Fc receptors. Proceedings of the National Academy of Sciences of the United States of America 105, 20167-20172. 
Scheid, J.F., Mouquet, H., Ueberheide, B., Diskin, R., Klein, F., Oliveira, T.Y., Pietzsch, J., Fenyo, D., Abadir, A., Velinzon, K., et al. (2011). Sequence and structural convergence of broad and potent HIV antibodies that mimic CD4 binding. Science 333, 1633-1637.

Schrödinger, L. (2011). The PyMOL Molecular Graphics System (The PyMOL Molecular Graphics System).

Shields, R.L., Namenuk, A.K., Hong, K., Meng, Y.G., Rae, J., Briggs, J., Xie, D., Lai, J., Stadlen, A., Li, B., et al. (2001). High resolution mapping of the binding site on human IgG1 for Fc gamma RI, Fc gamma RII, Fc gamma RIII, and FcRn and design of IgG1 variants with improved binding to the Fc gamma $R$. The Journal of biological chemistry 276, 6591-6604.

Smith, P., DiLillo, D.J., Bournazos, S., Li, F., and Ravetch, J.V. (2012). Mouse model recapitulating human Fcgamma receptor structural and functional diversity. Proceedings of the National Academy of Sciences of the United States of America 109, 6181-6186.

Sondermann, P., Huber, R., and Jacob, U. (1999). Crystal structure of the soluble form of the human fcgamma-receptor Ilb: a new member of the immunoglobulin superfamily at $1.7 \mathrm{~A}$ resolution. The EMBO journal 18, 1095-1103.

Sondermann, P., Huber, R., Oosthuizen, V., and Jacob, U. (2000). The 3.2-A crystal structure of the human IgG1 Fc fragment-Fc gammaRIII complex. Nature 406, 267-273.

Sondermann, P., Kaiser, J., and Jacob, U. (2001). Molecular basis for immune complex recognition: a comparison of Fc-receptor structures. Journal of molecular biology 309 , 737-749.

Sondermann, P., Pincetic, A., Maamary, J., Lammens, K., and Ravetch, J.V. (2013). General mechanism for modulating immunoglobulin effector function. Proc Natl Acad Sci U S A 110, 9868-9872.

Sprague, E.R., Martin, W.L., and Bjorkman, P.J. (2004). pH dependence and stoichiometry of binding to the Fc region of $\lg G$ by the herpes simplex virus Fc receptor gE-gl. J Biol Chem 279, 14184-14193.

Teplyakov, A., Zhao, Y., Malia, T.J., Obmolova, G., and Gilliland, G.L. (2013). IgG2 Fc structure and the dynamic features of the IgG $\mathrm{CH} 2-\mathrm{CH} 3$ interface. Molecular immunology 56, 131-139. 
a $\quad$ wtFc $\rightarrow$ FcyRIIIa $_{\mathrm{F} 158}$
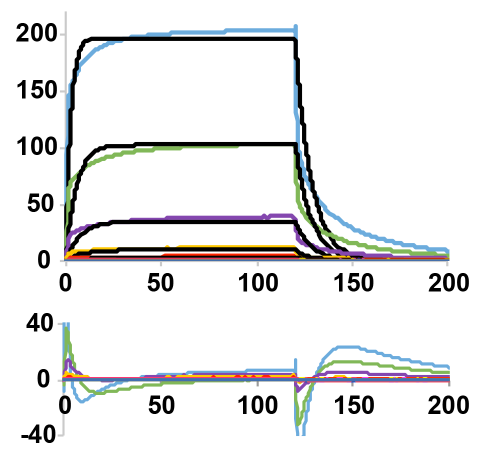

SDALIE FC $\rightarrow$ FcyRIIIa $_{\mathrm{F} 158}$

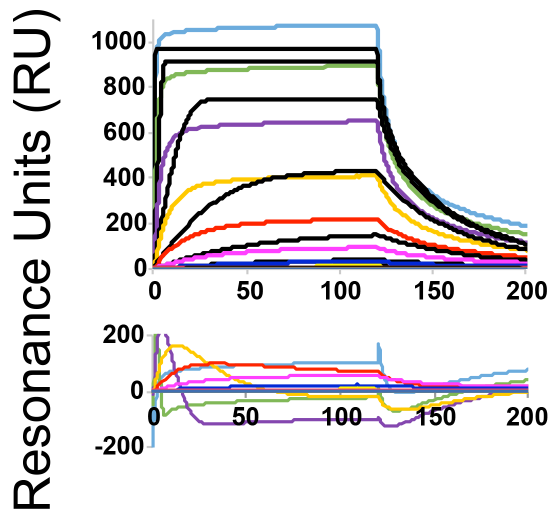

GASDALIE Fc $\rightarrow$ FcyRIIIa $_{\mathrm{F} 158}$
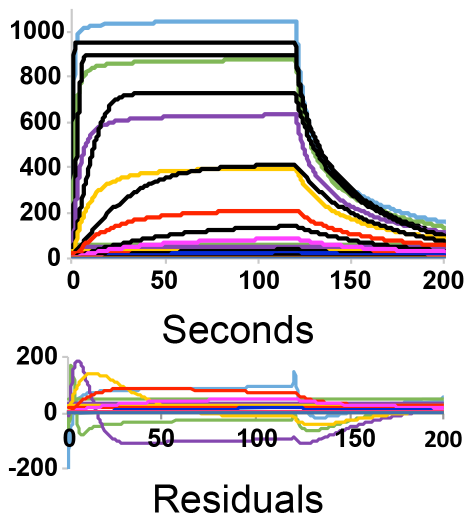

wtFc $\rightarrow$ FcyRlla $_{\mathrm{H} 131}$
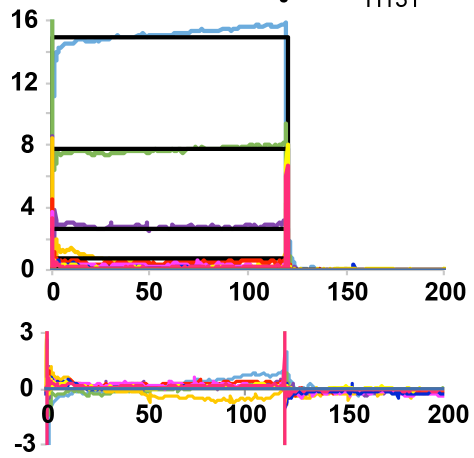

SDALIE Fc $\longrightarrow$ FcyRIIa $_{\mathrm{H} 131}$
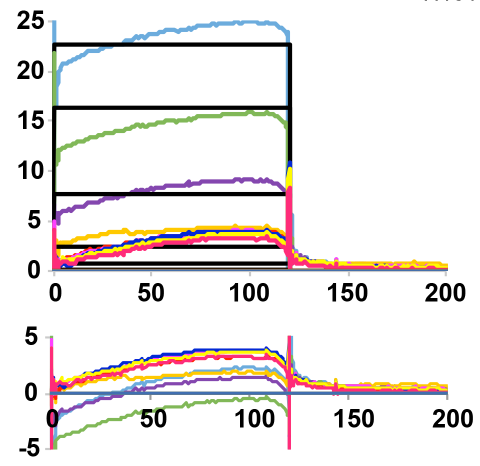

GASDALIE Fc $\longrightarrow$ FcyRIIa $_{\mathrm{H} 131}$

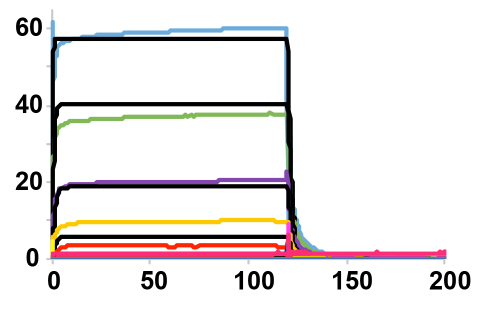

Seconds

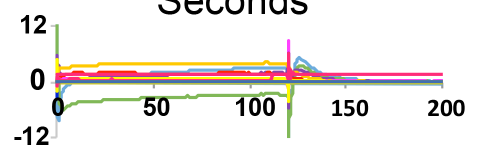

Residuals
wtFc $\rightarrow$ FcyRIIb
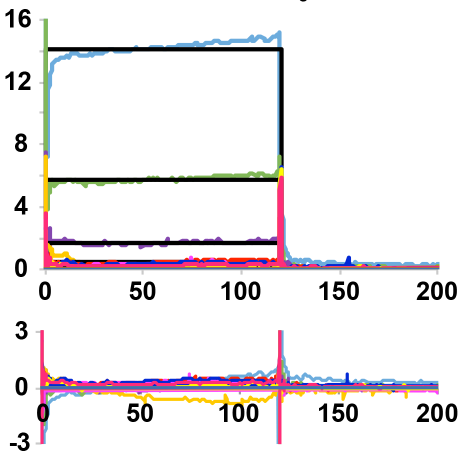

SDALIE Fc $\rightarrow$ FcyRIIb

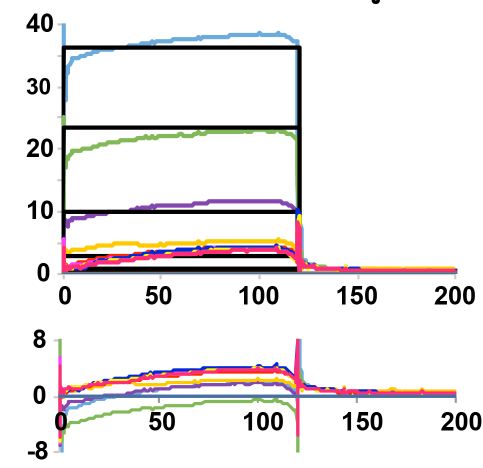

GASDALIE Fc $\rightarrow$ FcyRIIb 60
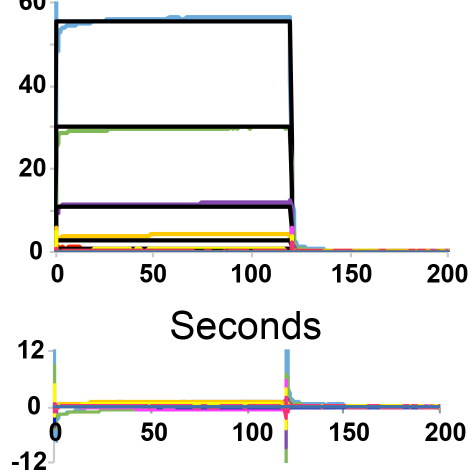

Residuals

$-10000 \mathrm{nM}=2500 \mathrm{nM}=625 \mathrm{nM}=156 \mathrm{nM}=39 \mathrm{nM}=9.7 \mathrm{nM}=2.4 \mathrm{nM}$

b
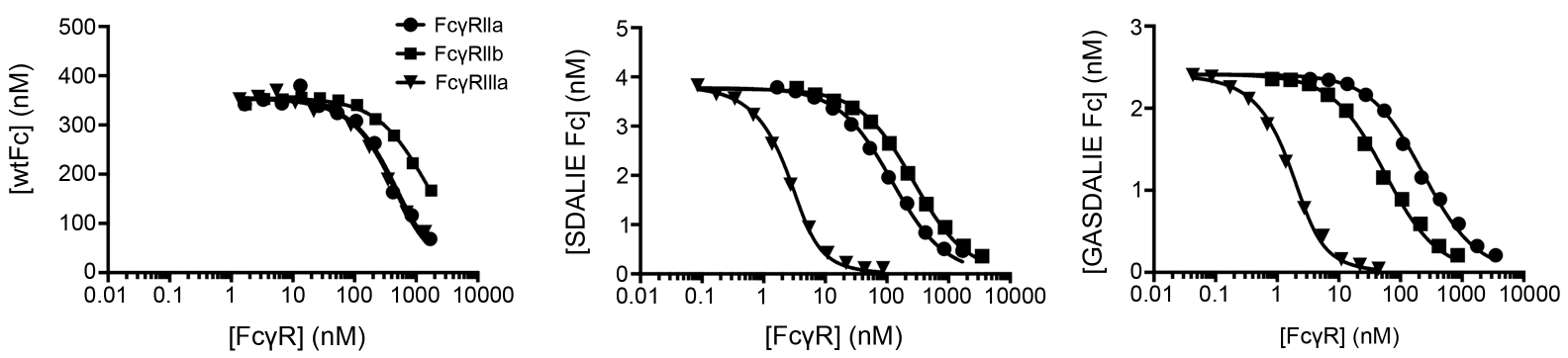
Figure 2
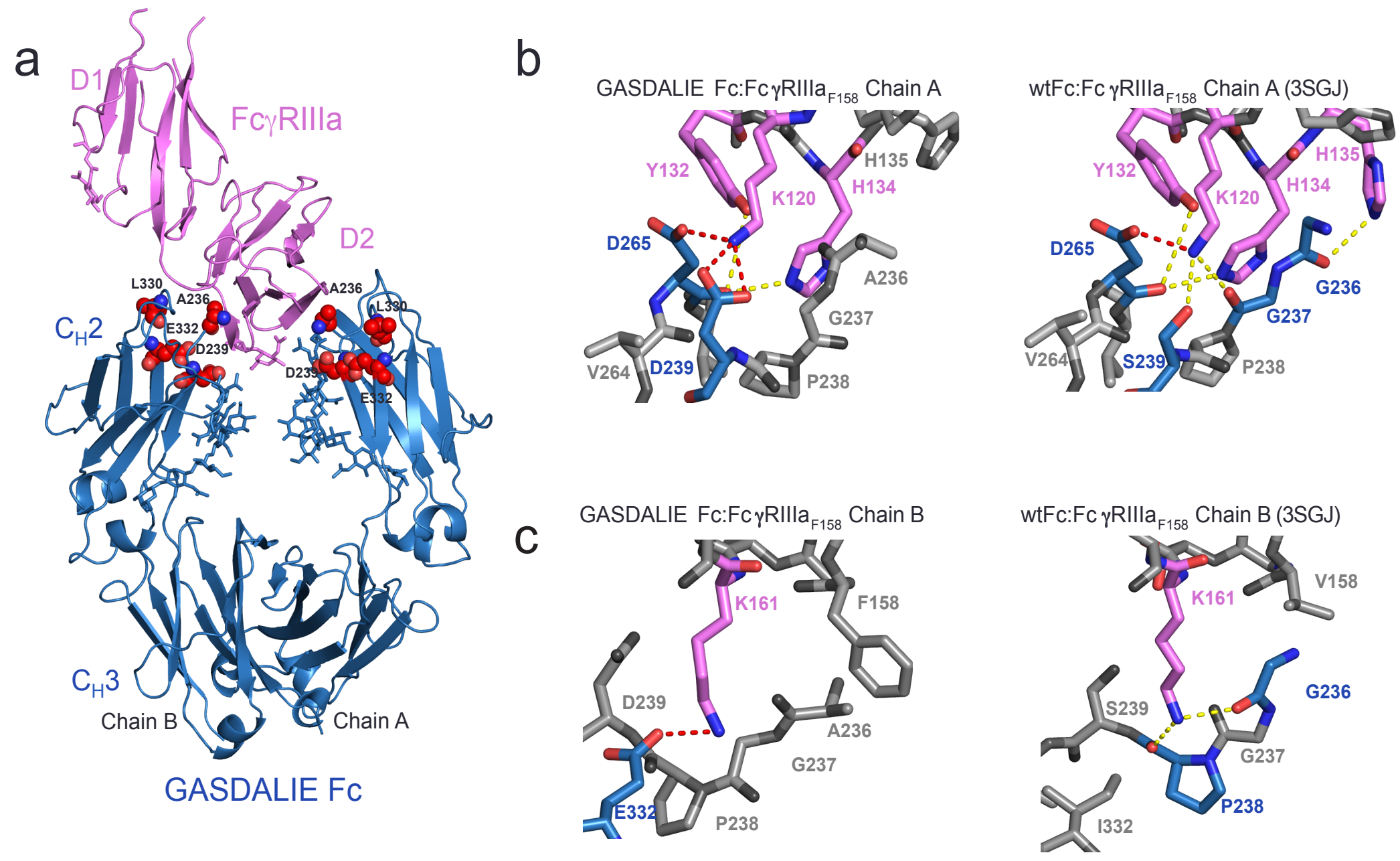
a

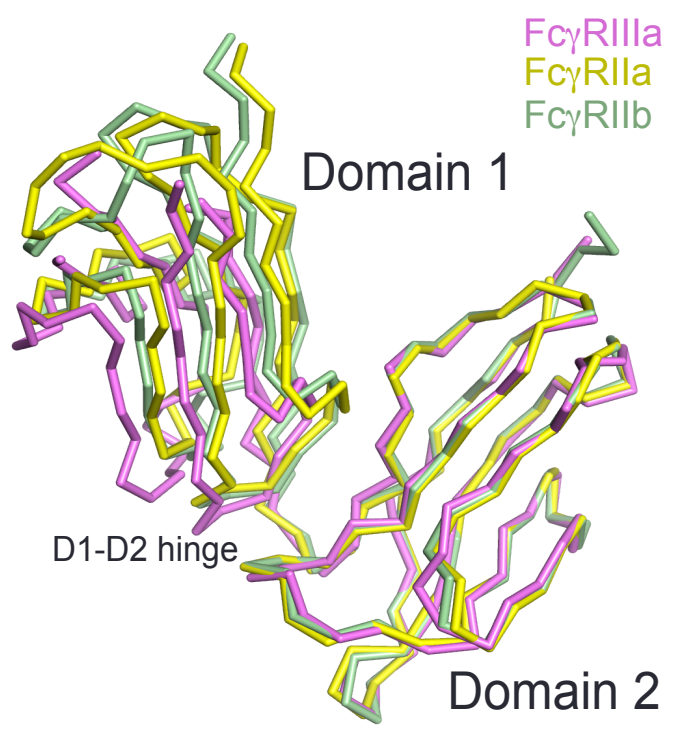

C GASDALIE Fc:FcyRlla Chain A

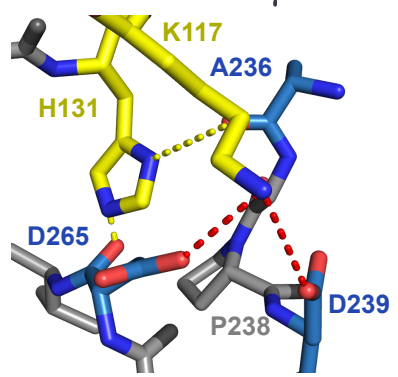

GASDALIE Fc:FcyRIllb Chain A

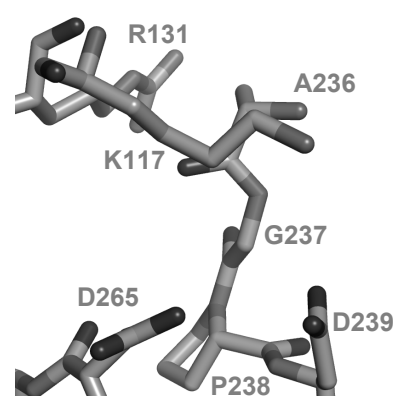

b

D1

FCYRIIIa PKAVVFLEPQWYRVLEKDSVTLKCOGAYSPEDNSTQWFHNESLISSOASSYFIDAATVD 64 FC $\gamma$ RIIa PKAVLKLEPPWINVLQEDSVTLTCQGARSPESDSIOWFHNGNLIPTHTQPSYRFKANNN 61 FCүRIIb PKAVLKLEPQWINVLQEDSVTLTCRGTHSPESDSIOWFHNGNLIPTHTOPSYRFKANNN 61

\section{D2}

FC $\gamma$ RIIIa DSGEYRCQTNLSTLSDPVQLEVHIGWLLLQAPRWVFKEEDPIHLRCHSWKNTALHKVTY 123 FCYRIIa DSGEYTCQTGQTSLSDPVHLTVLSEWLVLQTPHLEFOEGETIMLRCHSWKDKPLVKVTF 120 FC $\gamma$ RIIb DSGEYTCOTGQTSLSDPVHLTVLSEWLVLQTPHLEFOEGETIVLRCHSWKDKPLVKVTF 120

FC $\gamma$ RIIIa LQNGKGRKYFHHNSDFYIPKATLKDSGSYFCRGLFGSKNVSSETVNIT FC $\gamma$ RIIa FONGKSOKFSHLDPTFSIPQANHSHSGDYHCTGNIGYTLFSSKPVTIT FC $\gamma$ RIIb FQNGKSKKFSRSDPNFSIPQANHSHSGDYHCTGNIGYTLYSSKPVTIT

d GASDALIE Fc:FcyRlla Chain B

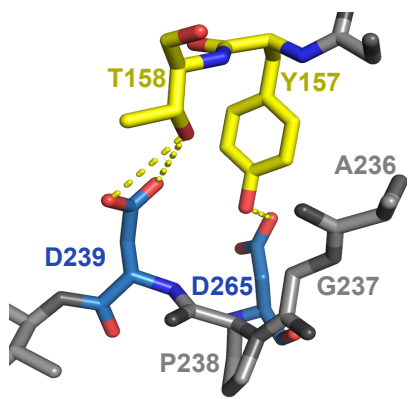

GASDALIE Fc:FcyRIIb Chain B
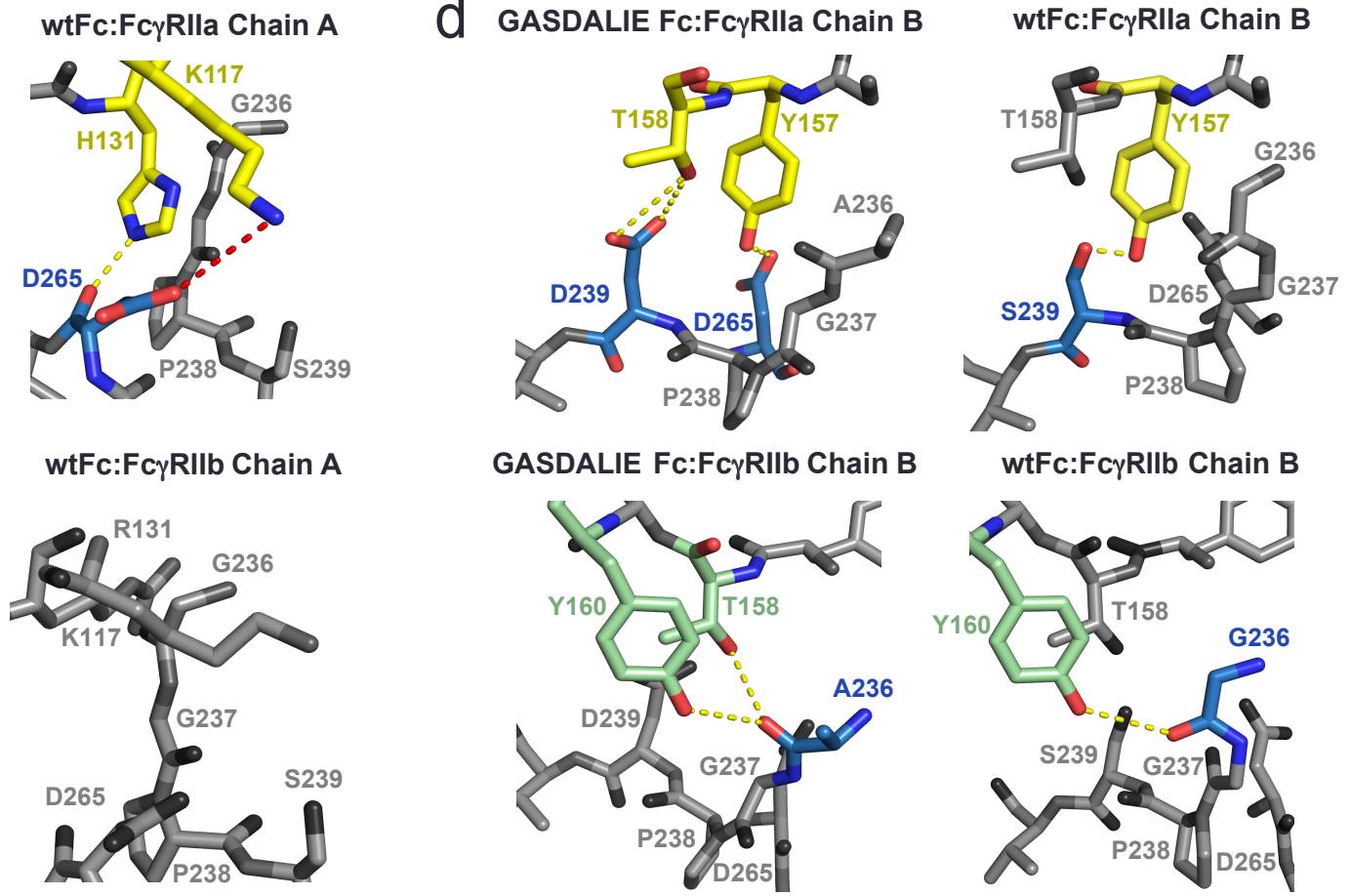

wtFc:Fc $\gamma$ RIlb Chain A

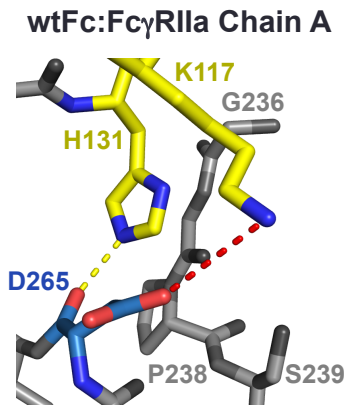

.

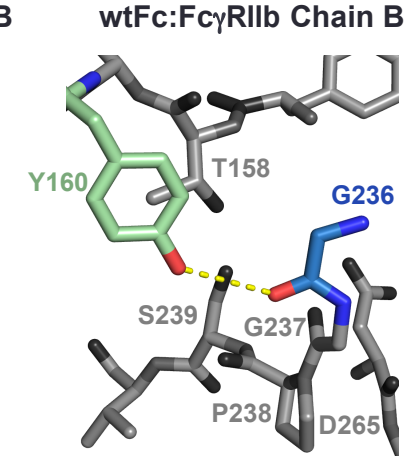

\section{Ahmed et al. Figure 3}


Figure 4

a

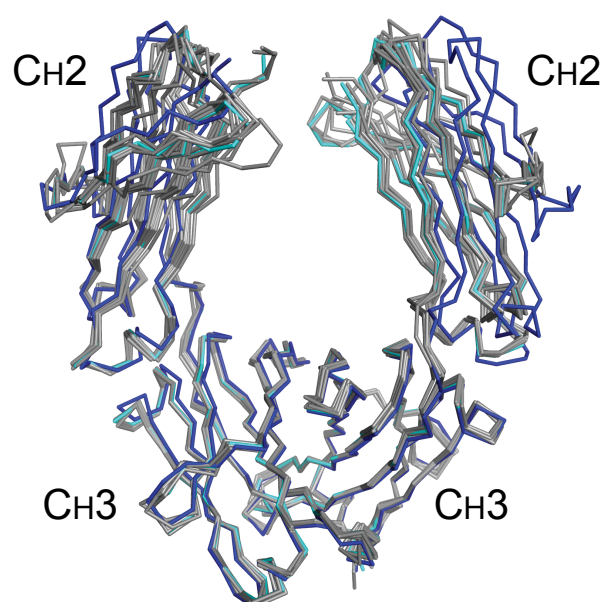

GASDALIE FC SDALIE Fc wtFc b

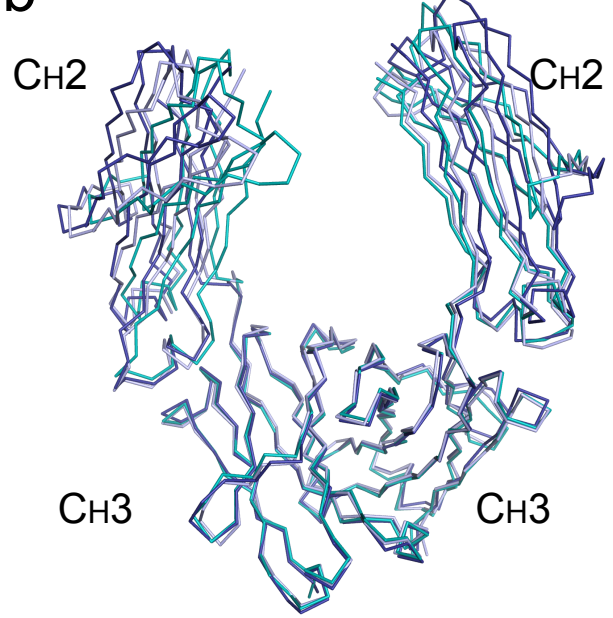

GASDALIE FC SDALIE Fc FCyRIIlla-bound GASDALIE FC
C

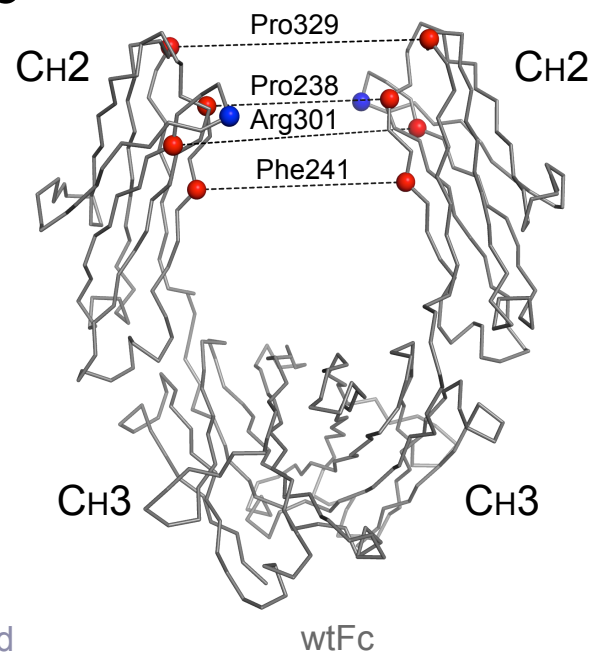

